Utah State University

DigitalCommons@USU

\title{
Seasonal and spatial variations in soil nitrogen and phosphorus supply rates in a boreal aspen forest
}

W.Z. Huang

J.J. Schoenau

Follow this and additional works at: https://digitalcommons.usu.edu/aspen_bib

Part of the Forest Sciences Commons

\section{Recommended Citation}

W.Z. Huang, J.J. Schoenau. 1997. Seasonal and spatial variations in soil nitrogen and phosphorus supply rates in a boreal aspen forest. Canadian Journal of Soil Science. 77(4): 597-612

This Article is brought to you for free and open access by the Aspen Research at DigitalCommons@USU. It has been accepted for inclusion in Aspen Bibliography by an authorized administrator of DigitalCommons@USU. For more information, please contact

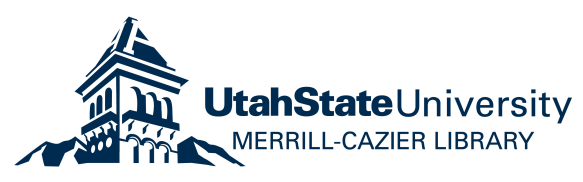




\title{
Seasonal and spatial variations in soil nitrogen and phosphorus supply rates in a boreal aspen forest
}

\author{
Wei Z. Huang ${ }^{1}$ and Jeff J. Schoenau \\ Department of Soil Science, University of Saskatchewan, Saskatoon, Saskatchewan, Canada S7N 5A8. E-mail: \\ schoenau@sask.usask.ca. Received 16 January 1997, accepted 21 July 1997.
}

\begin{abstract}
Huang, W. Z. and Schoenau, J. J. 1997. Seasonal and spatial variations in soil nitrogen and phosphorus supply rates in a boreal aspen forest. Can. J. Soil Sci. 77: 597-612. Soil nitrogen (N) and phosphorus (P) supply is one of the growth limiting factors in many forest ecosystems. Seasonal patterns in soil N and P supply rate were examined during a 2-yr period (1994-1995) for forest floor $(\mathrm{L}, \mathrm{F}$ and $\mathrm{H}$ ) and upper mineral (Ae) horizons in an 80-yr-old aspen forest in Saskatchewan, Canada. Accumulation of plant nutrient ions on ion exchange resins incubated in the field can provide an estimate of nutrient supply rate in soils because ion exchange resins have the potential ability to simulate nutrient flux to plant roots. Nutrient supply rates and the effect of plant uptake on nutrient supply rate was assessed using ion exchange membranes buried inside and outside polyvinyl chloride (PVC) cylinders. The difference between ion flux to the membranes inside (root uptake excluded) versus outside the cylinders was used as an index of plant nutrient uptake. From May to October, nutrient uptake $\left(\mu \mathrm{g} 10 \mathrm{~cm}^{-2} 2 \mathrm{wk}^{-1}\right)$ by plants ranged from 1.6 to $31.7\left(\mathrm{NO}_{3}{ }^{-}-\right.$ $\mathrm{N}$ ), from 2.7 to $13.7\left(\mathrm{NH}_{4}{ }^{+} \mathrm{N}\right)$ and from 2.6 to $12.7(\mathrm{P})$, with maximum $\mathrm{N}$ and $\mathrm{P}$ uptake in summer. Nutrient uptake by plants also varied among horizons. In general, plant uptake of $\mathrm{NO}_{3}{ }^{-}-\mathrm{N}, \mathrm{NH}_{4}{ }^{+} \mathrm{N}$ and $\mathrm{P}$ was highest in the $\mathrm{H}$ horizon, followed by the $\mathrm{F}$ and Ae horizons, with lowest uptake apparent in the L horizon. The results are consistent with the distribution of plant fine roots: most were found in the $\mathrm{H}$ horizon $(68 \%)$, followed by the Ae and $\mathrm{F}$ horizons $(15 \%)$, and the $\mathrm{L}(2 \%)$ horizon. Autumn litterfall represented a nutrient return of $28-40 \mathrm{~kg} \mathrm{~N} \mathrm{ha}^{-1}$ and $4-7 \mathrm{~kg} \mathrm{P} \mathrm{ha}^{-1}$ to the forest floor which coincided with an increase in ion supply rates in the forest floor. During the growing season, atmospheric inputs via bulk deposition and throughfall contributed small amounts of $\mathrm{N}\left(1.8 \mathrm{~kg} \mathrm{NH}_{4}^{+}-\mathrm{N} \mathrm{ha}^{-1}\right.$ and $\left.0.23 \mathrm{~kg} \mathrm{NO}_{3}^{-}-\mathrm{N} \mathrm{ha}^{-1}\right)$ and $\mathrm{P}\left(1.38 \mathrm{~kg} \mathrm{ha}^{-1}\right.$ inorganic $\left.\mathrm{P}\right)$ to the forest floor. Recycling of nutrients by litterfall and subsequent mineralization and re-assimilation by plant roots in the forest floor is a dynamic and important.component of nutrient cycling in boreal aspen forest ecosystems.
\end{abstract}

\section{Key words: Forest floor, ion exchange membranes, nutrient supply}

Huang, W. Z. et Schoenau, J. J. 1997. Variations saisonnières et spatiales des taux de disponibilité de l'azote et du phosphore du sol dans la tremblaie boréale. Can. J. Soil Sci. 77: 597-612. La disponibilité de l'azote (N) et du phosphore (P) du sol est l'un des facteurs qui limitent la croissance dans de nombreux écosystèmes forestiers. Nous avons examiné, sur une période de deux ans, l'allure saisonnière des taux d'approvisionnement de $\mathrm{N}$ et de $\mathrm{P}$ du sol dans la couche organique (horizons $\mathrm{L}, \mathrm{F}$ et $\mathrm{H}$ ) et dans les horizons minéraux supérieurs (Ae) d'une tremblaie de 80 ans, située en Saskatchewan au Canada. L'accumulation des nutriments végétaux sur des résines échangeuses d'ions mises à incuber sur le terrain peut fournir une estimation du taux de disponibilité des nutriments dans les sols, du fait de l'aptitude des résines à simuler le flux des nutriments vers les racines. Les taux de disponibilité des nutriments et l'effet de l'exportation par les plantes sur ces taux sont évalués au moyen de membranes d'échange ionique enterrées à l'intérieur et à l'extérieur de cyclindres en PVC. La différence entre le flux des ions vers les membranes intérieures (à l'exception de l'absorption racinaire) et le flux vers les membranes extérieures est utilisée comme index de l'absorption des nutriments par la plante. De mai à octobre, l'absorption de nutriments par les plantes, en $\mu \mathrm{g} 10 \mathrm{~cm}^{-2}$ par 2 semaines, s'étendait de 1,6 à $31,7(\mathrm{~N}-$

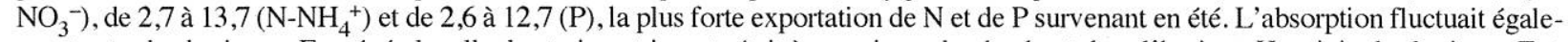
ment entre les horizons. En général, celle des trois nutriments était à son niveau le plus haut dans l'horizon $\mathrm{H}$, suivie des horizons $\mathrm{F}$ et Ae et en dernier de l'horizon L. Ces observations concordent avec la répartition des radicelles dans le sol, dont la plupart (68\%) se trouvaient dans l'horizon $\mathrm{H}, 15 \%$ chacun dans les horizons Ae et $\mathrm{F}$ et enfin $2 \%$ dans l'horizon L. Les retombées de litière en automne consistaient en une restitution à la couche organique de 28 à $40 \mathrm{~kg} \mathrm{~N}$ et de 4 à $7 \mathrm{~kg} \mathrm{P}$ par hectare, ce qui coïncidait avec un accroissement des taux d'approvisionnement ionique dans cette même couche. Durant la saison de végétation, les dépôts atmosphériques directs ou à les pluviolessivats apportaient de petites quantités de $\mathrm{N}\left(1,8 \mathrm{~kg} \mathrm{~N}_{-} \mathrm{NH}_{4}^{+}, 0,23 \mathrm{~kg} \mathrm{~N}-\mathrm{NO}_{3}^{-}\right.$et de $\mathrm{P}(1,38 \mathrm{~kg} \mathrm{P}$ minéral $)$ par hectare à la couche organique du sol. Le recyclage des nutriments par la litière et leur minéralisation et leur réassimilation subséquentes par les racines constituent une composante importante du cycle des nutriments dans l'écosystème de la tremblaie boréale.

Mots clés: Couche organique du sol forestier, membrane d'échange ionique, disponibilité des nutriments

The supply of plant available nitrogen $(\mathrm{N})$ and phosphorus (P) in forest soils, especially in the forest floor, can vary greatly with depth and season. The forest floor is important

\footnotetext{
${ }^{1}$ Present address: Department of Ecology, Evolution, and Natural Resources Cook College, Rutgers University, PO Box 231, New Brunswick, NJ 08904, USA.
}

to forest biogeochemical cycles and is essential for stand nutrition (Raulund-Rasmussen and Vejre 1995). Nutrients, largely in organic form, are returned to the forest floor as litterfall and converted into plant-available forms primarily through mineralization. Most mineralization and nitrification studies in forests have focused on the forest floor and the upper mineral soil (e.g., Boone 1992; Tietema et al. 1992, 1993). Persson and Wirén (1995) estimated that $78 \%$ 


\begin{tabular}{|c|c|c|c|c|c|c|c|c|c|c|c|}
\hline \multirow{3}{*}{$\begin{array}{l}\text { Slope } \\
\text { position }\end{array}$} & \multirow[b]{3}{*}{ Horizon } & \multicolumn{4}{|c|}{ Horizon thickness $(\mathrm{cm})$} & \multirow{3}{*}{$\begin{array}{l}\text { Bulk density } \\
\left(\mathrm{g} \mathrm{cm}^{-3}\right)\end{array}$} & \multirow[b]{3}{*}{$\mathrm{pH}$} & \multicolumn{4}{|c|}{ Organic nutrients $\left(\mathrm{g} \mathrm{kg}^{-1}\right)$} \\
\hline & & \multicolumn{3}{|c|}{ Aspect $^{\mathbf{y}}$} & \multirow[b]{2}{*}{ Mean } & & & \multirow[b]{2}{*}{$\mathrm{C}$} & \multirow[b]{2}{*}{$\mathrm{N}$} & \multirow[b]{2}{*}{$\mathrm{P}$} & \multirow[b]{2}{*}{ S } \\
\hline & & $\bar{E}$ & $\mathrm{~N}$ & $S$ & & & & & & & \\
\hline \multirow[t]{4}{*}{ Upper } & $\mathrm{L}$ & 2.0 & 2.0 & 2.0 & 2.0 & $0.075 \pm 0.015$ & $6.9 \pm 0.2$ & $432 \pm 15$ & $22 \pm 0.9$ & $1.6 \pm 0.2$ & $1.6 \pm 0.2$ \\
\hline & $\mathrm{F}$ & 3.0 & 3.0 & 3.0 & 3.0 & $0.091 \pm 0.012$ & $6.6 \pm 0.1$ & $385 \pm 34$ & $21 \pm 1.0$ & $1.3 \pm 0.1$ & $2.1 \pm 0.1$ \\
\hline & $\mathrm{H}$ & 3.0 & 5.0 & 5.0 & 4.3 & $0.21 \pm 0.010$ & $6.8 \pm 0.2$ & $344 \pm 41$ & $20 \pm 0.3$ & $1.3 \pm 0.1$ & $1.8 \pm 0.1$ \\
\hline & $\mathrm{Ae}$ & 10 & 8.0 & 9.0 & 9.0 & $1.27 \pm 0.025$ & $6.6 \pm 0.2$ & $8.8 \pm 2$ & $0.5 \pm 0.0$ & $0.2 \pm 0.0$ & $0.03 \pm 0.0$ \\
\hline \multirow[t]{4}{*}{ Mid } & $\mathrm{L}$ & 2.0 & 2.0 & 2.0 & 2.0 & $0.082 \pm 0.004$ & $6.2 \pm 0.3$ & $424 \pm 5$ & $20 \pm 0.8$ & $1.4 \pm 0.1$ & $1.9 \pm 0.1$ \\
\hline & $\mathrm{F}$ & 3.0 & 3.0 & 4.0 & 3.3 & $0.097 \pm 0.012$ & $6.5 \pm 0.1$ & $359 \pm 93$ & $22 \pm 1.0$ & $1.3 \pm 0.1$ & $2.2 \pm 0.2$ \\
\hline & $\mathrm{H}$ & 5.0 & 5.0 & 5.0 & 5.0 & $0.21 \pm 0.025$ & $6.5 \pm 0.1$ & $307 \pm 35$ & $20 \pm 0.5$ & $1.2 \pm 0.1$ & $2.0 \pm 0.1$ \\
\hline & $\mathrm{Ae}$ & 22 & 18 & 21 & 20 & $1.31 \pm 0.067$ & $6.6 \pm 0.2$ & $10.0 \pm 4$ & $0.5 \pm 0.0$ & $0.2 \pm 0.0$ & $0.04 \pm 0.0$ \\
\hline \multirow[t]{4}{*}{ Lower } & $\mathrm{L}$ & 2.0 & 3.0 & 3.0 & 3.0 & $0.082 \pm 0.008$ & $6.6 \pm 0.4$ & $429 \pm 21$ & $22 \pm 0.8$ & $1.7 \pm 0.2$ & $1.7 \pm 0.1$ \\
\hline & $\mathrm{F}$ & 3.0 & 7.0 & 5.0 & 4.7 & $0.11 \pm 0.028$ & $6.2 \pm 0.3$ & $393 \pm 17$ & $19 \pm 0.6$ & $1.5 \pm 0.1$ & $1.8 \pm 0.1$ \\
\hline & $\mathrm{H}$ & 3.0 & 17 & 12 & 11 & $0.22 \pm 0.006$ & $5.8 \pm 0.2$ & $366 \pm 43$ & $20 \pm 0.3$ & $1.3 \pm 0.1$ & $1.8 \pm 0.2$ \\
\hline & Aeg & 25 & 22 & 29 & 25 & $1.32 \pm 0.042$ & $5.9 \pm 0.4$ & $6.9 \pm 2$ & $0.7 \pm 0.0$ & $0.5 \pm 0.0$ & $0.05 \pm 0.0$ \\
\hline
\end{tabular}

$\mathrm{z}^{\mathrm{M}} \mathrm{Mean} \pm$ standard deviation $(n=5)$

$\mathbf{y}_{\mathrm{E}}=$ East transect, $\mathrm{N}=$ North transect $\mathrm{N}, \mathrm{S}=$ South transect

of the net $\mathrm{N}$ mineralization in several acid coniferous forests occurred in the organic layers and upper $10 \mathrm{~cm}$ of mineral soil, though net- $\mathrm{N}$ mineralization throughout the complete soil profile was not well documented.

A number of difficulties are encountered when attempting to assess nutrient availability in forest soils. Major problems include high spatial variability, temporal fluctuations in availability (Quesnel and Lavkulich 1981; Arp and Krause 1984; Johnson and Todd 1987; Cole 1995), and large variations in stand nutrient requirements (Federer 1983; White et al. 1988; Cole 1995). In addition, there is an overall lack of detailed understanding of $\mathrm{P}$ dynamics and availability in forests (Bernier 1984; Nilsson et al. 1995). These factors create a need for species and site-specific information on the distribution of soil nutrients and factors affecting their availability.

Several methods have been used to estimate patterns of nutrient mineralization and plant uptake in forest soils. Intact soil cores have been incubated in sealed plastic bags (Nadelhoffer et al. 1984), in covered PVC tubes (Adams and Attiwill 1986), or in uncovered thin metal cans (Raison et al. 1987) in the field. Ion exchange resin bags have also been placed in soil cores (inside and outside PVC tubes) in the field (Hart and Firestone 1991). The ion exchange resin method using resin both in bead and membrane forms has been used to assess nutrient supply rates in soils (Binkley 1984; Gibson et al. 1985; Gibson 1986; Casals et al. 1995; Qian and Schoenau 1995). Accumulation of plant nutrient ions on resins incubated in the field is considered to be one of the best methods for providing an estimate of nutrient supply rate in soils (Gibson et al. 1985; Gibson 1986) because ion exchange resins have the potential ability to simulate nutrient flux to plant roots (Skogley et al. 1990; Yang and Jacobsen 1990).

Resins in the form of membranes offer additional advantages because their flat structure ensures a constant surface area and better contact with soil (Cooperband and Logan 1994; Huang and Schoenau 1996a). Direct burial of ion exchange membranes in the soil under field conditions takes into account the many factors which affect nutrient ion flux to roots, including soil texture and structure. During the burial period, nutrient ions adjacent to the membrane that are already in the available form along with nutrients that are converted to the available form will be adsorbed onto the membrane surface. The amount of nutrient ion adsorbed on the membrane at the end of the burial period may therefore be considered an estimate of the potential nutrient ion supply rate to a plant (Huang and Schoenau 1996a; Schoenau and Greer 1996; Qian and Schoenau 1997). Burial times of one hour are convenient for instantaneous measurements of nutrient ion supply rate, while longer term periods of up to 2-wk (Schoenau and Greer 1996; Qian and Schoenau 1997) integrate more of the factors affecting availability, such as organic matter decomposition rates.

Few studies of nutrient dynamics have been conducted in boreal aspen forest soils, which occupy a large area $(9.27 \times$ $106 \mathrm{ha}$ ) of the southern boreal region in Western Canada (Forestry Canada 1988). We tested the hypothesis that nutrient supply rates would vary seasonally among horizons, slope positions and aspects due to differences in moisture content, soil temperature, vegetation uptake, and substrate additions. The objectives of this study were therefore to examine the seasonal and spatial patterns of soil $\mathrm{N}$ and $\mathrm{P}$ supply rate and the factors affecting it under aspen forest stands in the southern boreal region of Saskatchewan, Canada. A novel technique involving in situ burial of ion exchange membranes was used in the study to follow changes in potential supply rates of nutrient ions to an ion sink.

\section{MATERIALS AND METHODS}

\section{Study Area}

The study site was within Prince Albert National Park $\left(53^{\circ} 38^{\prime} \mathrm{N}, 106^{\circ} 13^{\prime} \mathrm{W}\right), 80 \mathrm{~km}$ north of Prince Albert, Saskatchewan, Canada. The study site was part of the southern study area of the Boreal Ecosystem-Atmosphere Study (BOREAS), an international study to improve estimates of $\mathrm{CO}_{2}$ exchange in the boreal forest. The site was a pure trembling aspen (Populus tremuloides Michx.) stand about $80 \mathrm{yr}$ 
old. The average height of the trees was $21 \mathrm{~m}$ and stem density was 1569 live stems hat ${ }^{-1}$. The understory was dominated by a dense population ( $60 \%$ of understory) of beaked hazelnut (Corylus cornuta March.) about $2 \mathrm{~m}$ tall. Other understory plants include prickly rose (Rosa acicularis Lindl.), bunchberry (Cornus canadensis L.) and various grasses. Mean annual precipitation was $456 \mathrm{~mm}$ and mean annual temperature was $-0.2^{\circ} \mathrm{C}$, a typical climate for the southern boreal region. The topography at the site was dominated by hillslopes and the soil was a sandy loam Gray Luvisol of glacial till origin (Waitville association, Canadian System of Soil Classification, Canada Soil Survey Committee 1987). The soil profile had clearly distinguishable L, F, and $\mathrm{H}$ horizons. Soil physical and chemical properties are presented in Table 1.

Three transects with different aspects (East, North and South) were selected in adjacent areas $(100 \mathrm{~m}$ by $100 \mathrm{~m})$ for the research performed in 1994. The slope of the east transect (transect E) was 30\%, and the distance from the foot to the upper slope was $42 \mathrm{~m}$. The slopes of the north transect (transect $\mathrm{N}$ ) and the south transect (transect $\mathrm{S}$ ) were $23 \%$, and the distance from the foot to the upper slope of the transects was $30 \mathrm{~m}$. The 1995 study was conducted at a lower slope position on transect $\mathrm{E}$.

\section{Ion Exchange Membrane Nutrient Supply Rate Assessment}

ION EXCHANGE MEMBRANE PROBE CONSTRUCTION. The probe $(15.2 \times 2.8 \times 0.5 \mathrm{~cm}$, Fig. 1) was made of ion exchange membrane (IEM) enclosed in a plastic frame (Schoenau et al. 1993). The anion-exchange membrane (BDH product no. 55164) and cation-exchange membrane (BDH product no. 55165) were in a sheet rather than in the form of beads. The structure of the membrane was polystyrene cross-linked with divinyl benzene (Schoenau and Huang 1991; Schoenau et al. 1993; Qian and Schoenau 1995; Huang and Schoenau 1996a). The IEM probes (Western Ag Innovation, Saskatoon) can be easily inserted into the soil with minimum soil disturbance, and are easily retrieved.

Procedure. Before insertion into the soil, the exchange sites on the resin in the probes were saturated with sodium bicarbonate $\left(\mathrm{HCO}_{3}^{-}\right)$by soaking in $0.5 \mathrm{M} \mathrm{NaHCO}_{3}(\mathrm{pH} 8.5)$ overnight (Qian and Schoenau 1995; Huang and Schoenau 1996a). Following a 2-wk burial period (Adams et al. 1989; Schoenau and Greer 1996; Qian and Schoenau 1997), the probes were removed from the soil and washed free of soil with deionized water. Washed probes were transferred to clean Ziploc ${ }^{(B)}$ bags and $20 \mathrm{~mL}$ of $0.5 \mathrm{M} \mathrm{HCl}$ was added as eluent to remove adsorbed ions. The probes were shaken with $0.5 \mathrm{M} \mathrm{HCl}$ for $1 \mathrm{~h}$ on a gyratory shaker (60 r.p.m.). Following elution, the probes were removed from the bags, washed with deionized water, and placed in $0.5 \mathrm{M} \mathrm{NaHCO}_{3}$ $(\mathrm{pH} 8.5)$ to resaturate exchange sites with sodium bicarbonate in preparation for re-use. Inorganic $\mathrm{N}$ as nitrate $\left(\mathrm{NO}_{3}{ }^{-} \mathrm{N}\right)$ and ammonium $\left(\mathrm{NH}_{4}{ }^{+} \mathrm{N}\right)$ in the $0.5 \mathrm{M} \mathrm{HCl}$ eluent was determined colorimetrically using a Technicon Autoanalyzer System (Technicon 1973). Phosphate-P was determined by the acid molybdate blue method (Murphy and Riley 1962).

\section{Study}

FIELD EXPERIMENTS. Nitrogen and P supply rates were measured by in situ burial of IEM probes for 11 sequential 2-wk intervals (Schoenau and Greer 1996; Qian and Schoenau 1997) from 12 May to 13 October 1994. Three small pits separated by a spacing of $1 \mathrm{~m}$ were excavated at each of three slope positions (upper, mid, lower) along each of the three transects in the study area. The IEM probes were then inserted horizontally into the middle of each of the $\mathrm{L}, \mathrm{F}, \mathrm{H}$ and $\mathrm{Ae}$ horizons in each pit. After the probes were inserted, the soil pits were filled with the original soil. Another set of IEM probes were inserted into the horizons of the same pit following removal of the previous set after the 2 -wk interval. A total of 216 IEM probes (108 anion +108 cation exchange membrane probes) were used per sampling interval.

Nutrient accumulation on the resin membrane during the burial period may be considered as an estimate of the potential nutrient supply rate to an absorbing surface such as a plant root (Gibson et al. 1985; Casals et al. 1995; Huang and Schoenau 1996a; Schoenau and Greer 1996). Nutrient accumulation rate was expressed as $\mu \mathrm{g}$ of nutrient adsorbed per $10 \mathrm{~cm}^{2}$ of resin surface area over 2 wk (i.e., $\mu \mathrm{g} 10 \mathrm{~cm}^{-2} 2$ $\mathrm{wk}^{-1}$ ) and used as a measure of nutrient supply rates.

LABORATORY EXPERIMENTS. Five soil samples of the forest floor (L, F and $\mathrm{H}$ each) and upper mineral (Ae) horizons were randomly collected from each of the upper, mid and lower slope positions of the transects in August 1994. Fieldmoist samples ( $50 \mathrm{~g}$ for $\mathrm{L}$ and $100 \mathrm{~g}$ for $\mathrm{F}$ and $\mathrm{H}$ ) of each forest floor horizon were transferred to $150-\mathrm{mL}$ polyethylene vials. An IEM probe was vertically inserted directly into the soil within each vial and incubated at $20^{\circ} \mathrm{C}$ under aerobic conditions for $2 \mathrm{wk}$. Deionized water was added daily to maintain the soil at field-moist conditions.

MEASUREMENT OF SOIL MOISTURE AND TEMPERATURE. Gravimetric water content and temperature of the L, F, H and Ae horizons was measured at each slope position on the three transects every 2 -wk. Soil temperature was measured by installing two thermocouples in each horizon and recorded using a thermocouple digital thermometer.

\section{Study}

FIELD EXPERIMENTS AND SAMPLE COLLECTION. All the 1995 field research was carried out at the lower slope position of transect E. Nutrient supply rate with and without plant root competition was estimated in 1995 using IEM probes inserted inside and outside of soil cores bounded by PVC cylinders (Nadelhoffer et al. 1984, 1985; Hart and Firestone 1991). Sampling was carried out at the study area, in four randomly selected replicates. A sharpened galvanized iron cylinder was used to sever the plant roots before installation of a PVC cylinder (10 $\mathrm{cm}$ in diameter by $18 \mathrm{~cm}$ in length). A total of eight holes, which were designed to match the L, F, $\mathrm{H}$ and Ae horizons, were cut in the wall of each cylinder. Four of the holes were prepared for inserting IEM probes, and the other four holes were prepared for inserting thermocouples to measure soil temperature. A small pit was then excavated beside the PVC cylinder. The IEM probes were inserted horizontally into the middle of the L, F, H and Ae 


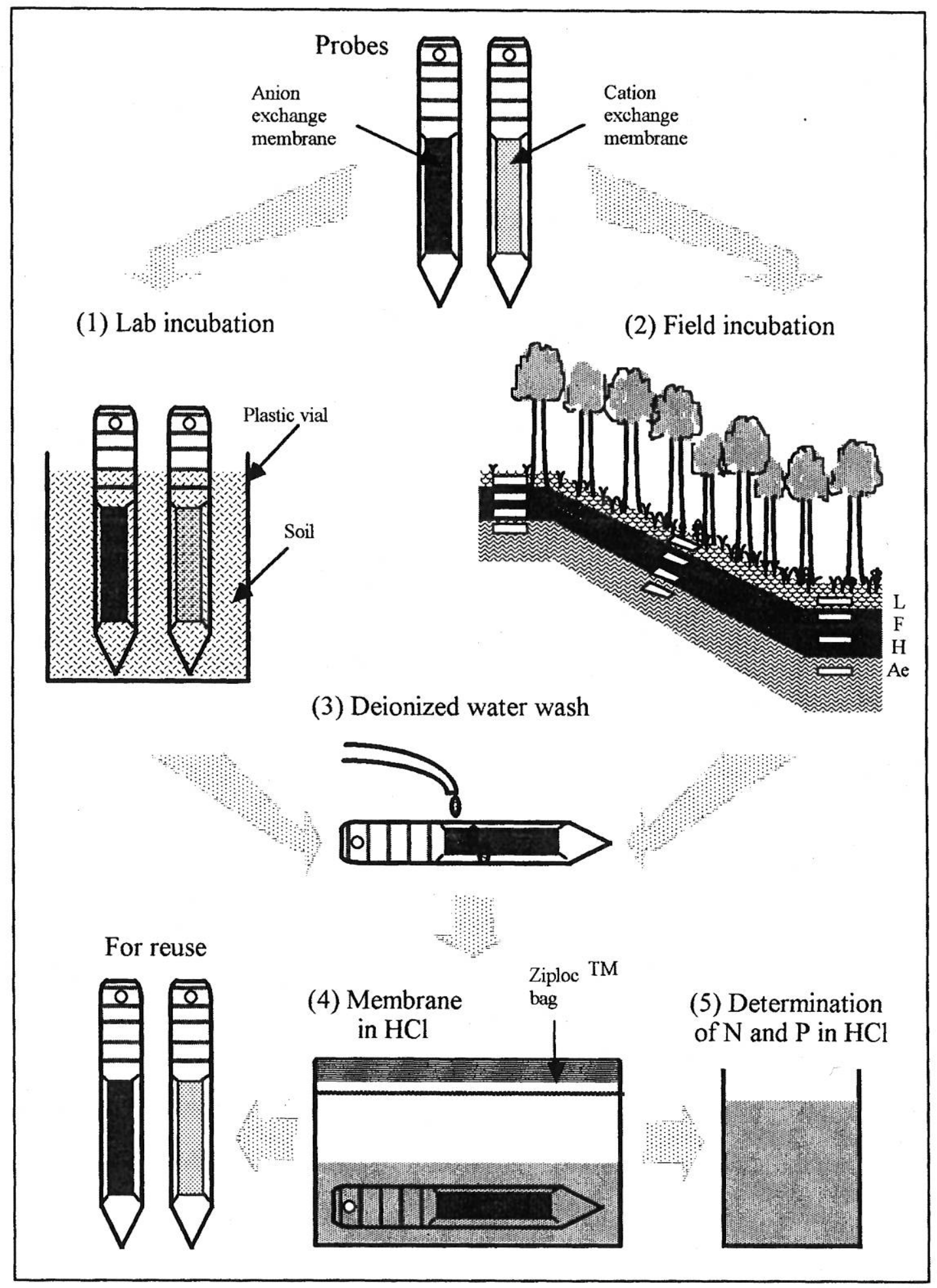

Fig. 1. Procedure for the IEM probe in situ measurement of nutrient supply rate: (1) laboratory incubation, IEM probe is inserted in soil in a plastic vial; (2) field incubation, IEM probe is buried in the L, F, H and Ae horizons; (3) after incubation, the IEM probe is cleaned with deionized water; (4) the IEM probe is then eluted with $0.5 \mathrm{M} \mathrm{HCl}$ solution, and (5) nitrogen and $\mathrm{P}$ concentrations in eluent are determined.

horizons inside and outside the cylinder, along with the thermocouples to measure soil temperature. After the IEM probes and thermocouples were inserted, the soil pit was filled with the original soil. Nutrient ion accumulation on the membranes over a 2-wk period was determined once a month from May to October 1995. 
At the end of each incubation period, soil temperature inside and outside the cylinders was measured before the IEM probes were removed. Soil samples of the L, F, H and Ae horizon were then collected from inside and outside the cylinders, and a further set of cylinders, IEM probes and thermocouples was inserted for the next sequential incubation in a randomly selected nearby new location within each of the replicate plots. Soil moisture was estimated gravimetrically.

WATER EXTRACTION MEthod. Soluble N and P in soil samples (from inside and outside of the PVC cylinders) were measured using a water extraction procedure (SornSrivichai et al. 1988; Huang and Schoenau 1996b) to provide an indication of the size of the potentially available soil $\mathrm{N}$ and $\mathrm{P}$ pool. In this procedure, $10 \mathrm{~g}$ (L, F, and $\mathrm{H}$ horizons) or $20 \mathrm{~g}$ (Ae horizon) field-moist soil removed from the field was shaken with $50 \mathrm{~mL}$ of deionized water for 1 hour, filtered through a single sheet of Whatman number 42 filter paper and then filtered through a membrane filter $(0.45 \mu \mathrm{m})$. A total of 64 samples ( 4 field replicates $\times 4$ horizons $\times 3$ lab replicates $\times 2$, inside and outside) were analyzed for each of the sampling times. The extracts were measured for water soluble $\mathrm{N}$ and $\mathrm{P}$ concentration as outlined above, and $\mathrm{N}$ and $\mathrm{P}$ concentrations were adjusted to an oven dry basis and reported as $\mathrm{mg} \mathrm{kg}^{-1}$ soil.

UPTAKE OF NITROGEN AND PHOSPHORUS BY VEGETATION. It was assumed that installation of cylinders did not significantly alter the rate of nutrient release and supply to the resin membranes from the soil inside the cylinders (Hart and Firestone 1991). The impact of root uptake in reducing nutrient supply to the resin membrane was calculated as ion adsorbed by the resin inside the cylinders (roots excluded) minus the ion adsorbed by resin placed outside the cylinders where roots compete with the resin for nutrients. The difference reflects the effect of root uptake and so may be taken as a relative indicator of nutrient flux to, and uptake by, nearby roots. Similarly, the differences in water soluble N and $\mathrm{P}$ concentration inside and outside the cylinders are considered to reflect the effect of plant uptake and were calculated using the same method.

BulK DEPOSITION AND THROUGHFALl COLLECTION. Bulk deposition (rainfall and dry deposition) and throughfall were collected once every 2 -wk (a total of 10 collections) from May to October 1995 on the lower slope of transect E. Each collector consisted of a 15-cm-diameter polypropylene funnel fixed through the cap of a 1-L Nalgene bottle (Blew et al. 1993). To prevent microbial activity and subsequent changes in species of $\mathrm{N}$, a small amount of phenyl mercuricacetate was added before placing the collectors in the field (Blew et al. 1993).

For collection of bulk deposition, three collectors were placed close to the ground in an open area at the study site. For collection of hazel throughfall, three collectors were placed close to the ground under a hazel canopy with no aspen overstory. The collector bottles were partially buried in the soil to prevent the collectors from tipping, and the upper of the funnel was $20 \mathrm{~cm}$ above the forest floor. For collection of aspen throughfall, three collectors were fixed on wooden stakes above the hazel canopy ( $2 \mathrm{~m}$ height) at the study site. Sample volumes were measured, then filtered through Whatman number 42 filter paper and analyzed for $\mathrm{N}$ and $\mathrm{P}$ concentrations as outlined above. The bulk deposition inputs provided base line inputs of $\mathrm{N}$ and $\mathrm{P}$. Inputs from the aspen and hazel canopies were calculated by subtracting bulk deposition from throughfall.

Total $\mathrm{N}$ in solution was determined by digestion with potassium persulfate $\left(\mathrm{K}_{2} \mathrm{~S}_{2} \mathrm{O}_{8}\right)$, and Devarda's alloy was added to reduce all $\mathrm{N}$ to $\mathrm{NH}_{4}^{+}-\mathrm{N}$ (Raveh and Avnimelech 1979). Total $\mathrm{P}$ in solution was measured by ammonium persulfate digestion $\left(\left(\mathrm{NH}_{4}\right)_{2} \mathrm{~S}_{2} \mathrm{O}_{8}\right)$ (Menzel and Corwin 1965; Gales et al. 1966). Organic $N$ and $P$ were estimated as the difference between total and inorganic determinations.

LitTERFALl COLLECTION. Four litter traps were placed at the study site on the lower slope of transect E. The litter traps were polyethylene boxes with a surface area of $1500 \mathrm{~cm}^{2}$ $(30 \times 50 \mathrm{~cm}, 23 \mathrm{~cm}$ tall $)$, with small holes in the bottom and in each side to allow water to drain out. Litterfall was collected monthly from July to October. The litterfall was dried at $70^{\circ} \mathrm{C}$ to a constant mass, weighed, ground and analyzed for total $\mathrm{N}$ and $\mathrm{P}$ concentration.

Fine ROOT COLLECTION. Plant fine roots $(\leq 3.0 \mathrm{~mm}$ diameter $)$ in the L, F, H and Ae horizons were sampled in August 1995 using a root auger at the study area. The root auger consisted of a saw cutting edge welded to a stainless steel cylinder (15 cm tall and $8 \mathrm{~cm}$ inside diameter). Ten soil cores were collected, each soil core was separated into L, F, H and Ae horizons, and the roots were carefully separated from the soil and washed. The roots were dried at $70^{\circ} \mathrm{C}$, weighed and analyzed for total $\mathrm{N}$ and $\mathrm{P}$ concentration. Total $\mathrm{N}$ and total $\mathrm{P}$ in the leaf litter (1994 and 1995 samples) and root samples were measured by hot digestion with $\mathrm{H}_{2} \mathrm{SO}_{4}$ and peroxide (Raveh and Avnimelech 1979; Thomas et al. 1967).

STATISTICAL ANALYSES. The 1994 measured nutrient supply rates by time of the year, horizon, slope position and aspects were analyzed by analysis of variance with repeated measures (ANOVAR) using the SuperANOVA computer program (Abacus Concepts, Inc. 1989). The moisture and temperature data from the 1995 study were examined by one-way analysis of variance (ANOVA). Inputs of $\mathrm{N}$ and $\mathrm{P}$ by aspen throughfall, hazel throughfall and bulk deposition data from each collection were pooled to determine the total average and standard deviation. Linear regressions were used to examine the relationship between nutrient supply rate at different depths, and soil moisture and temperature, and $\mathrm{N}$ and $\mathrm{P}$ uptake and fine root distribution.

\section{RESULTS AND DISCUSSION}

\section{Seasonal Patterns in Nitrogen and Phosphorus Supply Rate}

Soil inorganic $\mathrm{N}$ and $\mathrm{P}$ supply rate varied widely among horizons, slope positions and times of the year. However, there was no statistically significant difference in nutrient supply rates among the aspects. The measured nutrient supply rates from the transects were therefore combined for each 
(a) $\mathrm{NO}_{3}-\mathrm{N}$

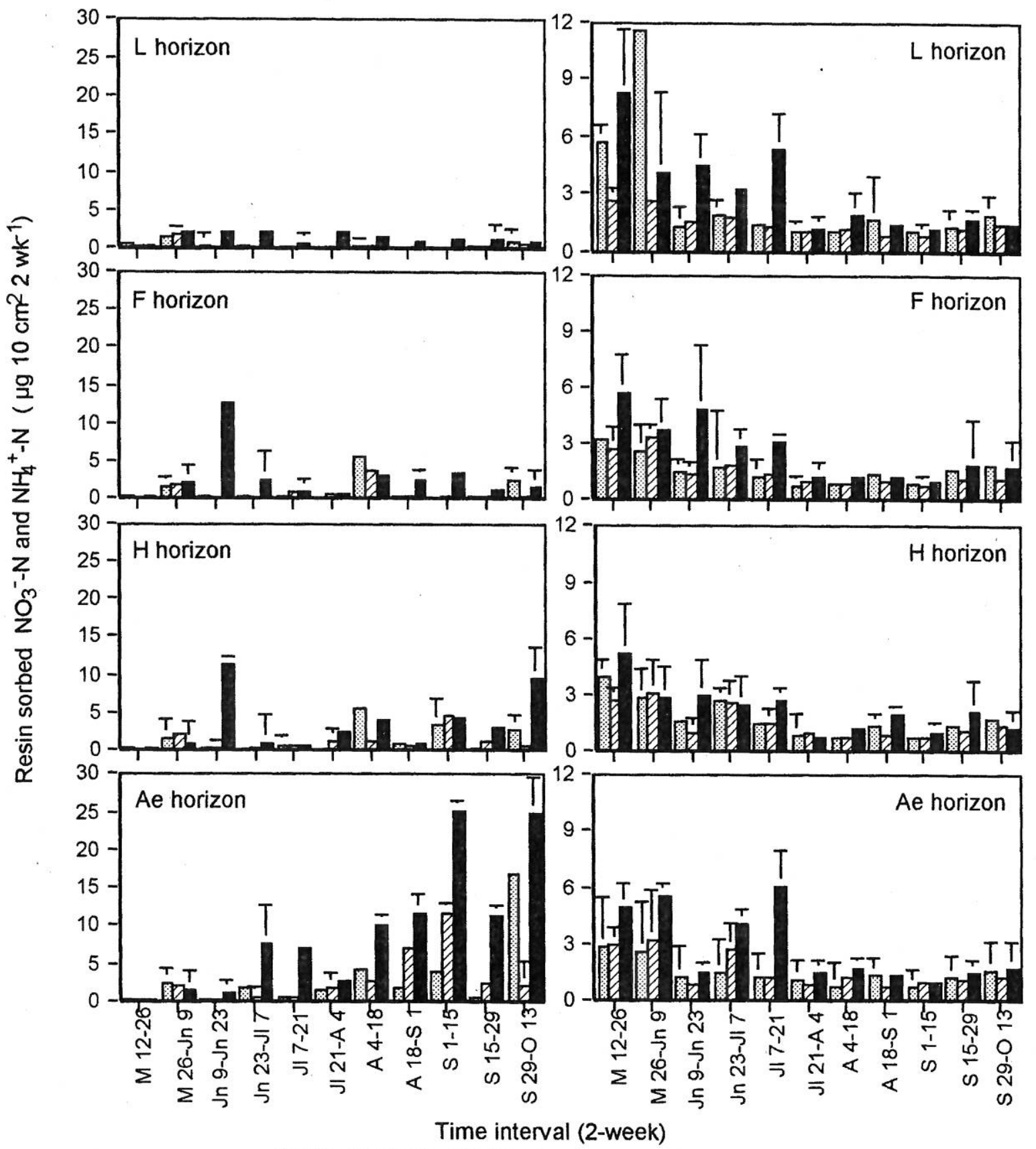

\section{Top slope $\square$ Mid slope Low slope}

Fig. 2. Seasonal and spatial patterns in inorganic nitrogen $\left(\mathrm{NO}_{3}{ }^{-}-\mathrm{N}\right.$ and $\left.\mathrm{NH}_{4}{ }^{+}-\mathrm{N}\right)$ supply rates in different horizons and slope positions at the study area (from 12 May to 13 October 1994).

slope position. Seasonal variations in soil $\mathrm{NO}_{3}{ }^{-}-\mathrm{N}$ and $\mathrm{NH}_{4}{ }^{+} \mathrm{N}$ supply rate by horizon, slope position and time of year did not follow the same pattern (Fig. 2), similar to observations in another recent study of $\mathrm{N}$ supply rates
(Casals et al. 1995). Minimal soil $\mathrm{NO}_{3}{ }^{-}-\mathrm{N}$ accumulation on the resin was generally observed during the first 2-wk measurement interval in early May (Fig. 2a), which perhaps reflects inhibition of nitrification by high moisture (Fig. 3a). 
(a) Soil moisture

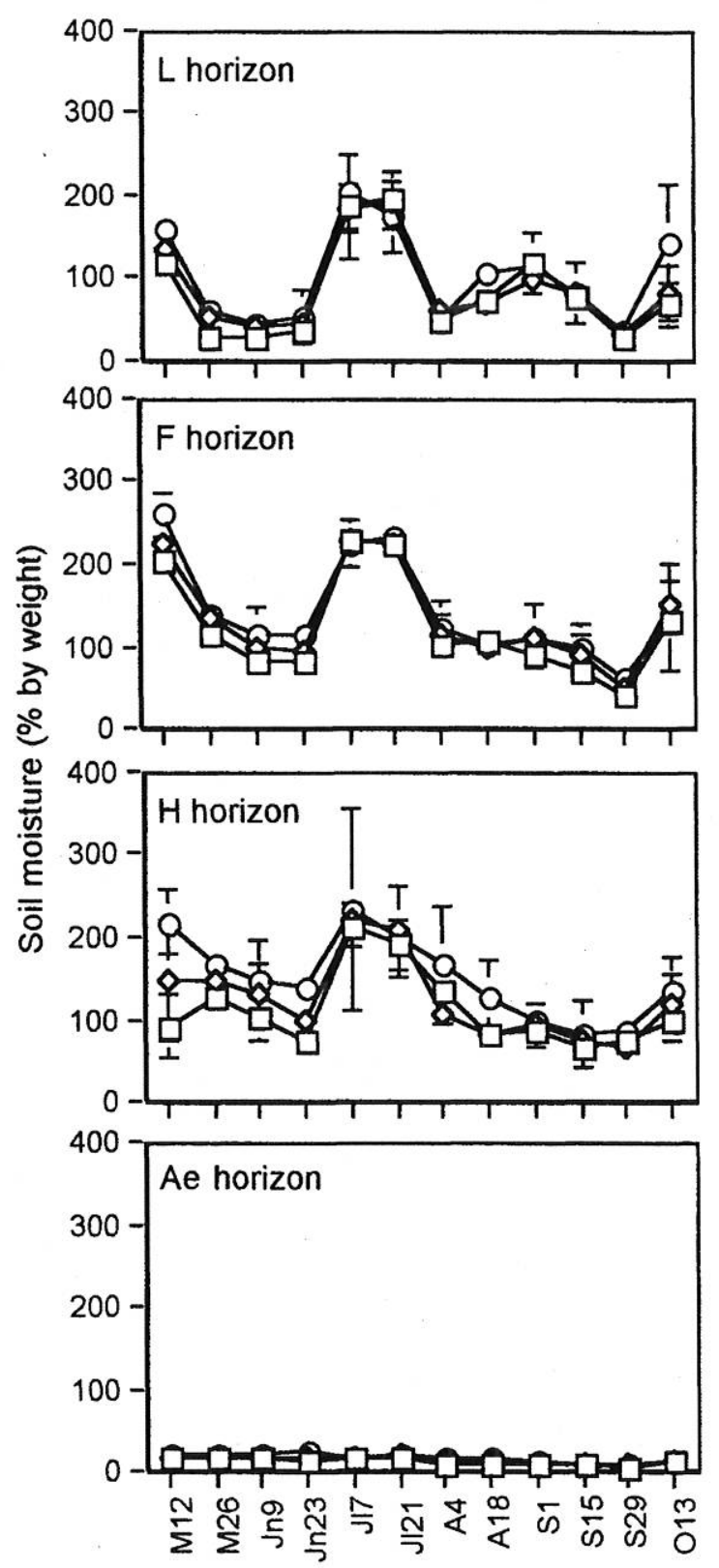

(b) Soil temperature

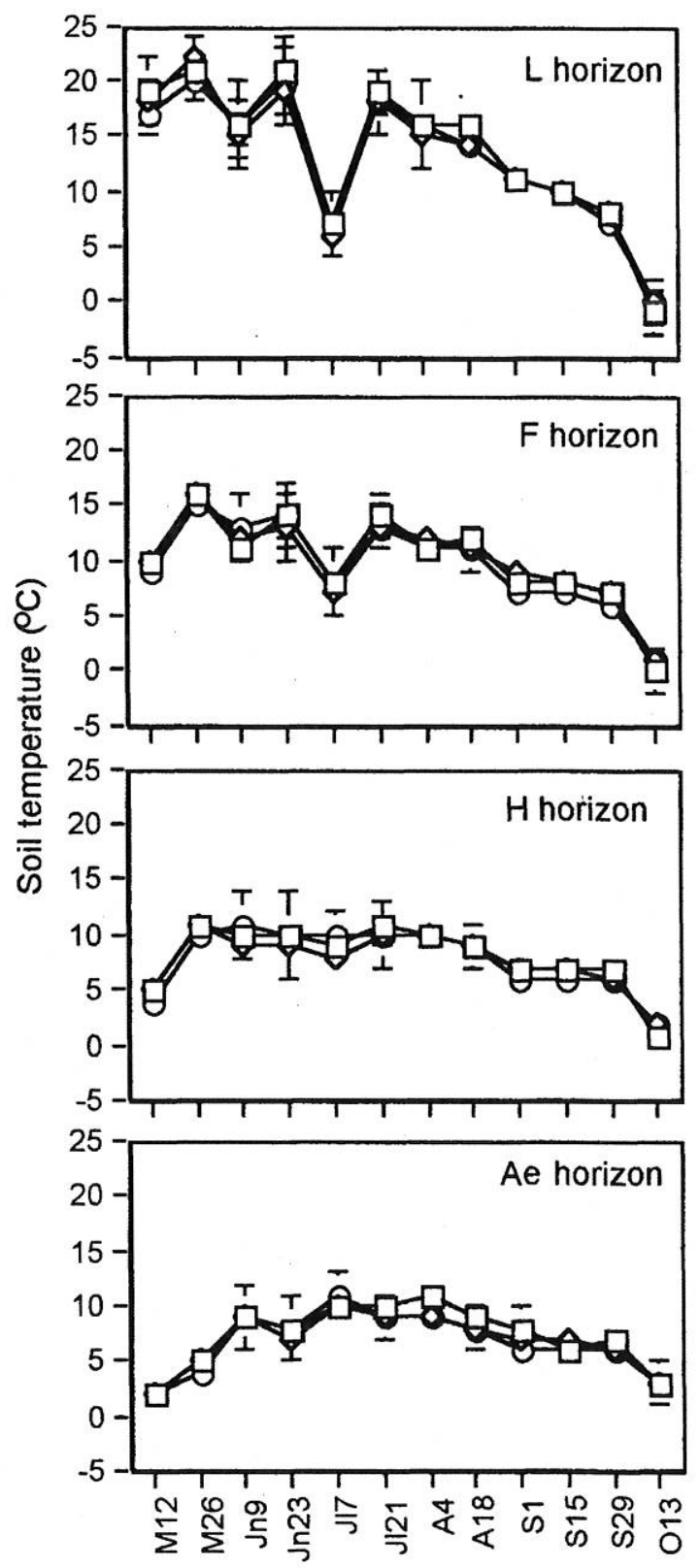

Time (month/date)

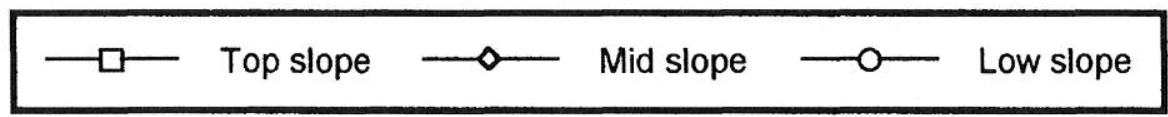

Fig. 3. Soil moisture (a) and temperature (b) of different horizons and slope positions at the study area from 12 May to 13 October 1994. (b) Soil temperature data are based on one daily measurement per 2-wk. Bars refer to one standard deviation.

However, low soil $\mathrm{NO}_{3}{ }^{-}-\mathrm{N}$ supply rate was not observed in July when moisture was also high. Maximum soil $\mathrm{NO}_{3}{ }^{-} \mathrm{N}$ accumulation on the resin in the Ae horizon occurred later in the growing season. In contrast to $\mathrm{NO}_{3}{ }^{-} \mathrm{N}$, maximum soil
$\mathrm{NH}_{4}{ }^{+}-\mathrm{N}$ accumulation on the resin membrane was in the first 2-wk burial period in May (Fig. 2b), perhaps reflecting high ammonification rates and low net nitrification rates early in the growing season (Casals et al. 1995). 
(a) Outside the cylinders
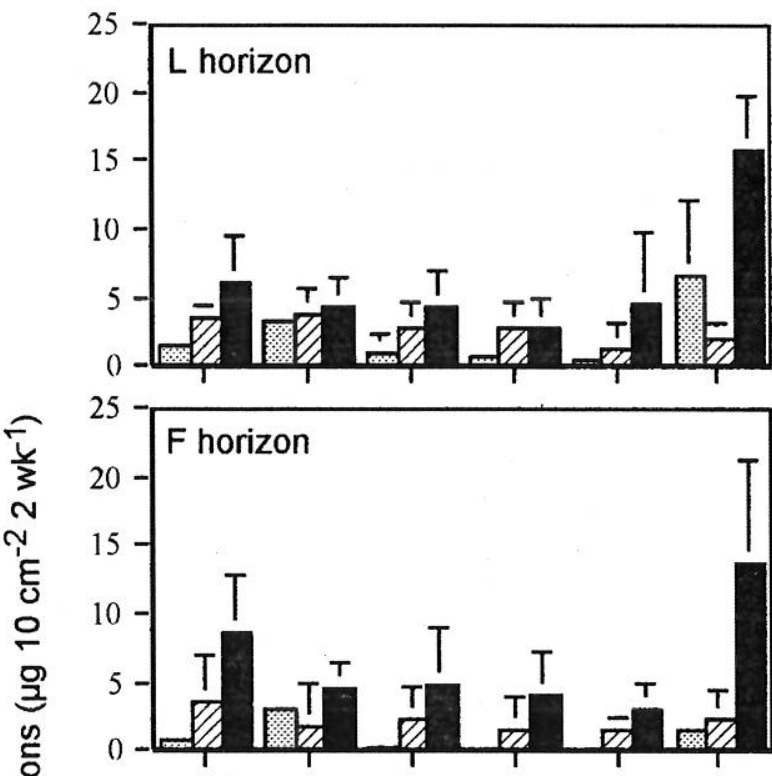

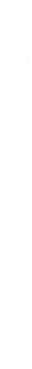
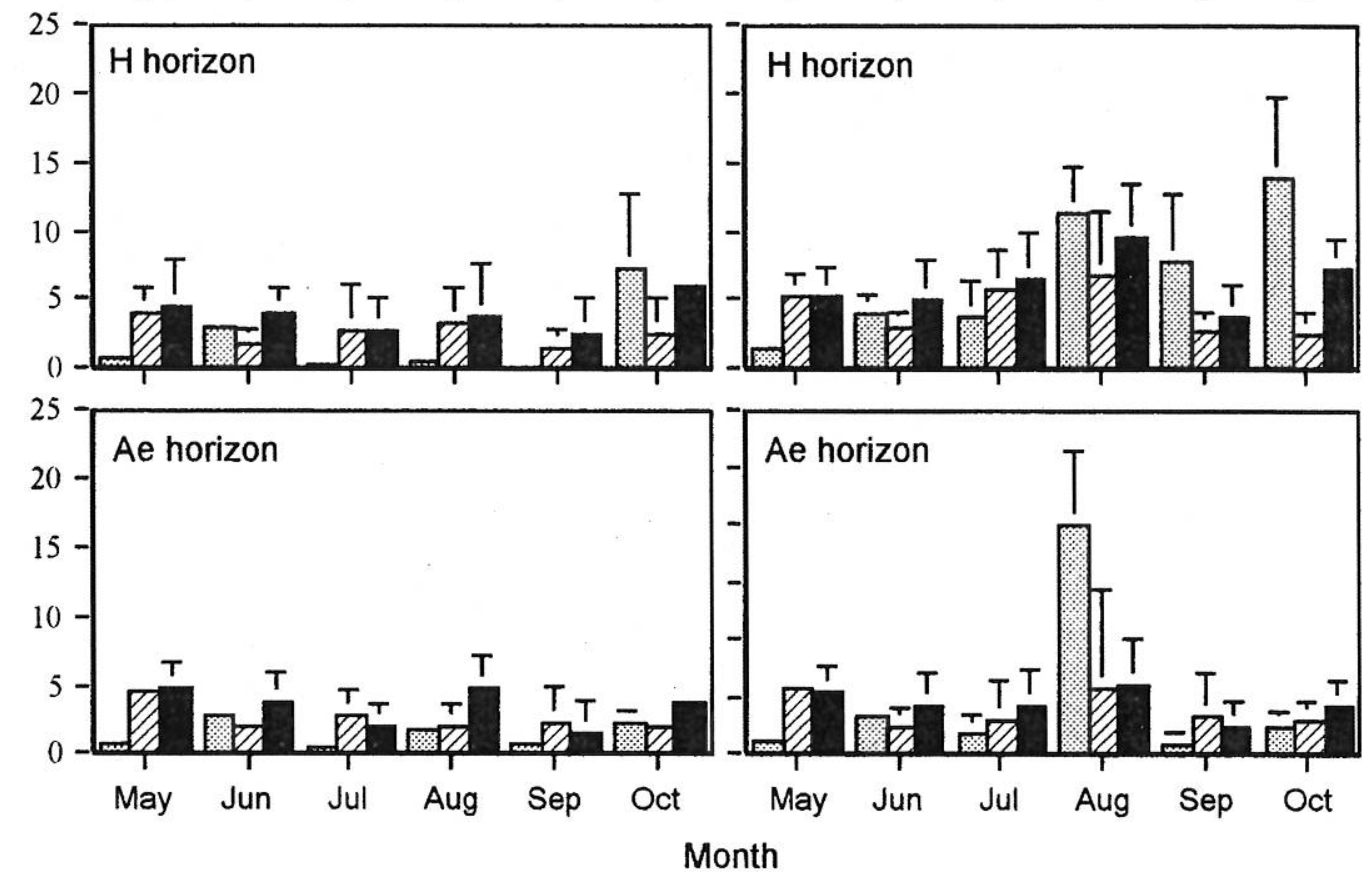

Month

(b) Inside the cylinders
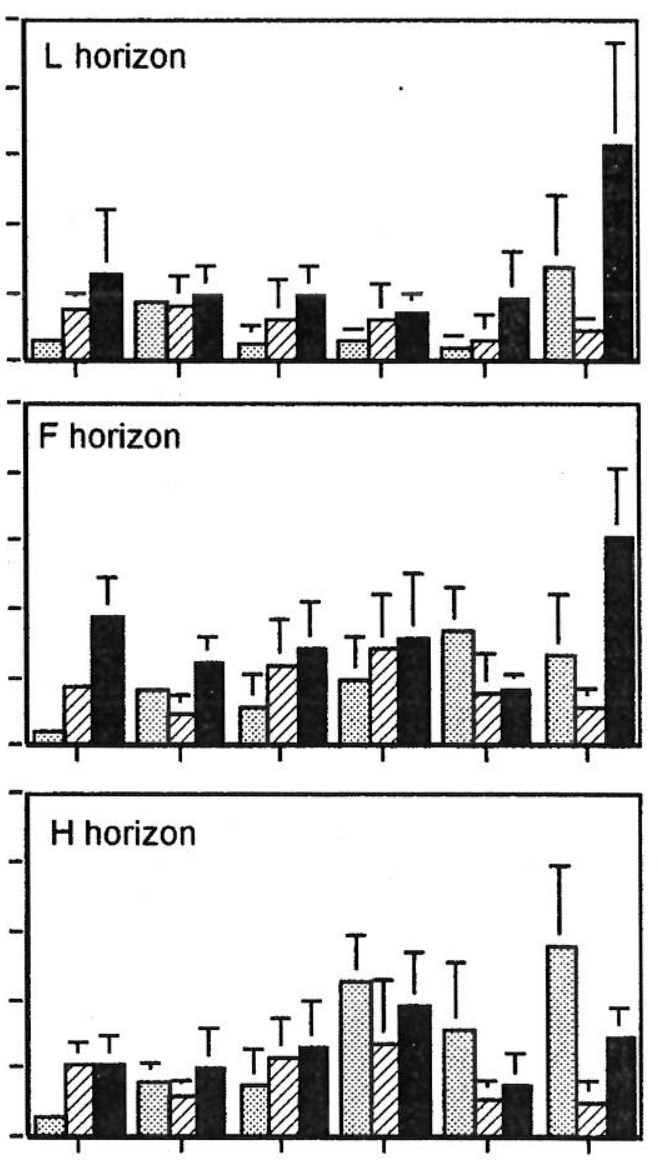

$$
\mathrm{NO}_{3}{ }^{-} \mathrm{N} \square \mathrm{NH}_{4}^{+}-\mathrm{N} \square \mathrm{PO}_{4}^{3--P}
$$

Fig. 4. Seasonal and spatial patterns in $\mathrm{N}$ and $\mathrm{P}$ supply rate in different horizons at the study site (17 May to 12 October 1995), bars refer to one standard deviation: (a) IEM probe incubated outside the PVC cylinder (allows for nutrient ion uptake and competition from plant roots); and (b) IEM probe incubated inside the PVC cylinder (nutrient ion uptake and competition from plant roots prevented).

The patterns of soil inorganic $\mathrm{N}\left(\mathrm{NO}_{3}{ }^{-}-\mathrm{N}\right.$ and $\left.\mathrm{NH}_{4}{ }^{+}-\mathrm{N}\right)$ supply rate at the lower slope position for different horizons over the 1995 growing season are presented in Fig. 4. The minimum soil $\mathrm{NO}_{3}{ }^{-}$- $\mathrm{N}$ supply to the resin membranes out- side the cylinder (Fig. 4a) was again in May while the maximum soil $\mathrm{NO}_{3}^{-}-\mathrm{N}$ supply was later in October, similar to the patterns observed for this slope position in 1994. In contrast to $\mathrm{NO}_{3}{ }^{-}-\mathrm{N}$, the maximum soil $\mathrm{NH}_{4}{ }^{+}-\mathrm{N}$ supply to the 


\begin{tabular}{|c|c|c|c|c|c|c|c|c|}
\hline \multirow[b]{2}{*}{ Time } & \multicolumn{2}{|c|}{ L horizon } & \multicolumn{2}{|c|}{ F horizon } & \multicolumn{2}{|c|}{$\mathrm{H}$ horizon } & \multicolumn{2}{|c|}{ Ae horizon } \\
\hline & Inside & Outside & Inside & Outside & Inside & Outside & Inside & Outside \\
\hline \multicolumn{9}{|c|}{ Soil moisture $(\% \text { by weight })^{\mathbf{y}}$} \\
\hline May & $12.8 \pm 1.2$ & $13.0 \pm 0.9$ & $39.4 \pm 3.2$ & $40.1 \pm 2.2$ & $162 \pm 13$ & $165 \pm 6.7$ & $21.6 \pm 2.3$ & $20.8 \pm 2.7$ \\
\hline Jun & $16.9 \pm 3.3$ & $17.7 \pm 1.0$ & $43.5 \pm 1.8$ & $45.2 \pm 1.4$ & $143 \pm 9.2$ & $136 \pm 11$ & $22.2 \pm 0.7$ & $19.4 \pm 2.0$ \\
\hline Jul & $43.1 \pm 1.6$ & $43.8 \pm 0.9$ & $79.1 \pm 2.6$ & $80.3 \pm 2.8$ & $111 \pm 4.3$ & $113 \pm 8.6$ & $12.4 \pm 1.0$ & $12.7 \pm 1.8$ \\
\hline Aug & $58.5 \pm 1.9$ & $61.0 \pm 5.4$ & $171 \pm 4.5$ & $179 \pm 2.0$ & $150 \pm 7.4$ & $157 \pm 9.4$ & $22.9 \pm 2.5$ & $23.3 \pm 2.0$ \\
\hline Sep & $38.7 \pm 1.7$ & $38.1 \pm 1.8$ & $70.2 \pm 3.7$ & $71.8 \pm 2.9$ & $92.4 \pm 2.2$ & $98.1 \pm 5.7$ & $15.0 \pm 0.4$ & $15.5 \pm 2.8$ \\
\hline Oct & $205 \pm 12$ & $212 \pm 18$ & $114 \pm 3.9$ & $122 \pm 6.0$ & $100 \pm 5.0$ & $98.0 \pm 3.9$ & $12.4 \pm 0.6$ & $13.5 \pm 2.0$ \\
\hline \multicolumn{9}{|c|}{ Soil temperature $\left({ }^{\circ} C\right)^{\mathrm{y}}$} \\
\hline May & $17.0 \pm 0.4$ & $17.6 \pm 0.9$ & $15.6 \pm 0.3$ & $14.1 \pm 0.6$ & $9.4 \pm 0.2$ & $8.6 \pm 0.1$ & $7.7 \pm 0.2$ & $6.9 \pm 0.2$ \\
\hline Jun & $18.5 \pm 0.6$ & $18.6 \pm 0.7$ & $16.2 \pm 0.3$ & $16.0 \pm 0.9$ & $10.8 \pm 0.9$ & $11.6 \pm 0.4$ & $8.3 \pm 0.1$ & $7.8 \pm 0.3$ \\
\hline Jul & $17.1 \pm 0.5$ & $17.5 \pm 0.8$ & $14.6 \pm 0.4$ & $15.3 \pm 0.8$ & $12.4 \pm 0.8$ & $12.6 \pm 0.7$ & $11.0 \pm 0.7$ & $11.6 \pm 0.7$ \\
\hline Aug & $17.7 \pm 0.4$ & $17.7 \pm 0.5$ & $11.3 \pm 0.7$ & $12.7 \pm 0.5$ & $10.2 \pm 0.5$ & $10.2 \pm 0.8$ & $9.5 \pm 0.3$ & $9.3 \pm 0.3$ \\
\hline Sep & $13.7 \pm 0.5$ & $13.9 \pm 0.7$ & $10.7 \pm 0.4$ & $12.0 \pm 0.5$ & $9.7 \pm 0.3$ & $10.0 \pm 0.3$ & $9.2 \pm 0.5$ & $9.2 \pm 0.3$ \\
\hline Oct & $3.7 \pm 0.2$ & $3.9 \pm 0.3$ & $3.9 \pm 0.3$ & $3.9 \pm 0.4$ & $4.0 \pm 0.3$ & $4.2 \pm 0.1$ & $4.3 \pm 0.2$ & $4.4 \pm 0.1$ \\
\hline
\end{tabular}

${ }^{\mathrm{z}}$ Soil moisture and temperature were measured at the end of each incubation period.

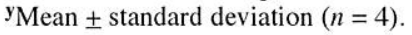

Table 3. Inputs of $\mathrm{N}$ and $\mathrm{P}$ in bulk deposition, aspen and hazel throughfall and leaf litterfall over the growing season (May to October) at the study site (1995)

\begin{tabular}{|c|c|c|c|c|c|c|c|}
\hline Source & Total N & $\mathrm{NO}_{3}{ }^{-}-\mathrm{N}$ & $\mathrm{NH}_{4}^{+}-\mathrm{N}$ & $\begin{array}{l}\text { Organic N } \\
\left(\mathrm{kg} \mathrm{ha}^{-1}\right)\end{array}$ & Total P & Inorganic $\mathrm{P}$ & Organic $\mathrm{P}$ \\
\hline Bulk deposition $^{\mathbf{z}}$ & $2.71(0.55)$ & $0.09(0.02)$ & $0.85(0.13)$ & $1.77(0.05)$ & $0.26(0.03)$ & $0.17(0.02)$ & $0.10(0.01)$ \\
\hline Aspen $^{y}$ & $2.18(0.53)$ & $0.01(0.13)$ & $0.51(0.13)$ & $1.66(0.51)$ & $0.63(0.14)$ & $0.56(0.13)$ & $0.07(0.01)$ \\
\hline Hazel $^{y}$ & $1.29(0.27)$ & $0.13(0.00)$ & $0.40(0.07)$ & $0.75(0.24)$ & $0.71(0.13)$ & $0.65(0.12)$ & $0.06(0.01)$ \\
\hline Sub-total & $6.18(1.33)$ & $0.23(0.04)$ & $1.77(0.25)$ & $4.18(1.25)$ & $1.61(0.21)$ & $1.38(0.19)$ & $0.22(0.02)$ \\
\hline Litterfall $(1995)^{\mathbf{x}}$ & $40.1(4.7)$ & $N^{w}$ & ND & ND & $6.6(0.8)$ & ND & ND \\
\hline Litterfall $(1994)^{\mathbf{v}}$ & $27.9(6.8)$ & & & & $3.7(0.9)$ & & \\
\hline Total & 46.3 & & & & 8.2 & & \\
\hline
\end{tabular}

${ }_{\mathrm{z}}$ Mean values of bulk deposition, aspen and hazel throughfall with pooled standard deviation in parentheses.

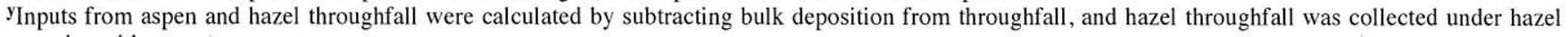
canopies with no aspen overstory.

${ }^{\mathbf{x}}$ Mean with standard deviation in parentheses $(n=4)$.

"ND denotes not determined.

${ }^{\mathrm{v}}$ Mean with standard deviation in parentheses $(n=9)$, collected by Huang and Schoenau (1996b).

resin membranes was again in May, as observed in 1994. The $\mathrm{NH}_{4}{ }^{+} \mathrm{N}$ supply to the resin membranes decreased in June, then increased slightly in July, and decreased again and reached a minimum in September 1995.

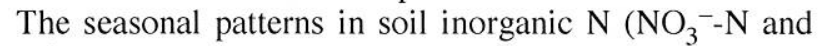
$\mathrm{NH}_{4}{ }^{+}-\mathrm{N}$ ) supply rates as assessed inside the cylinders (i.e., without the impact of root uptake) are presented in Fig. 4b. The results (Table 2) indicate that the installation of PVC cylinders resulted in less than a 5\% difference in soil moisture contents and temperature inside and outside the cylinders (bulk soil). Adams et al. (1989) have also reported no significant difference in soil moisture and temperature between core-incubated soil and bulk soil. Compared with the supply rate of $\mathrm{NO}_{3}{ }^{-} \mathrm{N}$ and $\mathrm{NH}_{4}{ }^{+}-\mathrm{N}$ to resin membranes outside the cylinders, higher soil $\mathrm{NO}_{3}{ }^{-} \mathrm{N}$ and $\mathrm{NH}_{4}{ }^{+}-\mathrm{N}$ supply to the resin membranes inside the cylinder were observed for the F, H and Ae horizons in July and August (Figs. 4 and 8). This suggested that mid-summer in this boreal aspen ecosystem is the time when inorganic ions released via mineralization is maximum and is also when the majority of ion uptake by plant roots occurs. Other studies also have suggested that vegetation uptake accounted for most of the observed decrease in inorganic $\mathrm{N}$ pool in forest soils (Vitousek and Matson 1985; Mitchell et al. 1992a).

The amounts of $\mathrm{NO}_{3}{ }^{-}-\mathrm{N}$ supplied to the resin membranes increased from September to October which probably relates to initial $\mathrm{NH}_{4}{ }^{+}-\mathrm{N}$ availability and organic matter addition through litterfall. The availability of $\mathrm{NH}_{4}{ }^{+}-\mathrm{N}$ can regulate nitrification rates (Adams 1986), and greater initial $\mathrm{NH}_{4}{ }^{+}-\mathrm{N}$ availability in the soil can result in higher amounts of $\mathrm{NO}_{3}{ }^{-} \mathrm{N}$ released after incubation (Casals et al. 1995). Therefore, the high $\mathrm{NH}_{4}{ }^{+}-\mathrm{N}$ availability in May would contribute to the subsequent increased nitrification and nitrate accumulation over the growing season. Leaf-fall started in July, with most litterfall in September and October. Average annual leaf litterfall $\left(\mathrm{kg} \mathrm{ha}^{-1}\right)$ was 2709 for 1994 and 3321 for 1995; corresponding $\mathrm{N}$ inputs $\left(\mathrm{kg} \mathrm{ha}^{-1}\right)$ were 28 for 1994 and 40 for 1995 (Table 3). Similar amounts (33-38 kg N $\mathrm{ha}^{-1}$ ) of total $\mathrm{N}$ returned through annual litterfall have been reported for aspen forest stands in north and north central Minnesota (Alban 1982; Perala and Alban 1982).

Over the 1994 growing season, inorganic P supply rates to buried anion exchange membranes ranged from 0.11 to $31 \mu \mathrm{g} 10 \mathrm{~cm}^{-2} 2 \mathrm{wk}^{-1}$ in the different horizons (Fig. 6). 
Minimum soil $\mathrm{P}$ supply rate was in the middle of the growing season, and maximum supply rate was observed at the last sampling date. Similar patterns in soil P supply rates in different horizons in the lower slope of transect were observed again in 1995 (Fig. 4a). Minimum soil P supply to the resin membrane was from July to September, and the maximum soil $\mathrm{P}$ supply rates were in October. The seasonal patterns in soil $\mathrm{P}$ supply rates inside the cylinders (root excluded) are presented in Fig. 4b. Similar patterns in P supply rates were observed in spring and fall (September and October). However, the patterns varied in the middle of the growing season (July and August) when uptake of P by trees and understory plants was likely at its maximum, giving rise to low P supply rates to membranes buried outside the cylinders.

Different amounts of $\mathrm{P}$ returned to soil through litterfall have been reported for different forests. For hardwood forests in the northern United States of America, amounts of $\mathrm{P}$ returned to soil through litterfall were reported to be 3.1 $\mathrm{kg} \mathrm{P} \mathrm{ha}^{-1} \mathrm{yr}^{-1}$ (Zhang and Mitchell 1995) and $4.0 \mathrm{~kg} \mathrm{P} \mathrm{ha}^{-1}$ $\mathrm{yr}^{-1}$ (Gosz et al. 1972). For aspen forests, $\mathrm{P}$ input to soil in litterfall was reported to be $8.0 \mathrm{~kg} \mathrm{P} \mathrm{ha}^{-1} \mathrm{yr}^{-1}$ in north central Minnesota (Perala and Alban 1982). Another source of $\mathrm{P}$ inputs to forest soils is precipitation, and values of $0.34 \mathrm{~kg}$ $\mathrm{P} \mathrm{ha}^{-1} \mathrm{yr}^{-1}$ have been reported in Wisconsin (Boyle et al. 1973) and $2.6 \mathrm{~kg} \mathrm{P} \mathrm{ha}^{-1} \mathrm{yr}^{-1}$ in northeastern Minnesota (Silkworth and Grigal 1982). In this study, the amounts of $P$ returned through annual leaf litterfall was $3.7 \mathrm{~kg} \mathrm{P} \mathrm{ha}^{-1}$ for 1994 and 6.6 for 1995 . The P inputs to soil through bulk deposition was $0.26 \mathrm{~kg} \mathrm{P} \mathrm{ha}^{-1}$ over the growing season (May to October, Table 3).

\section{Spatial Patterns in Nitrogen and Phosphorus Supply Rate}

In addition to seasonal patterns, inorganic $\mathrm{N}$ and $\mathrm{P}$ supply rate exhibited variability with respect to slope position and soil horizon. The supply rate of $\mathrm{NO}_{3}{ }^{-}-\mathrm{N}$ and $\mathrm{NH}_{4}{ }^{+}-\mathrm{N}$ was higher in the lower slope position than the mid and upper slope positions in many of the sampling intervals (Fig. 2). The amounts of $\mathrm{NO}_{3}{ }^{-}-\mathrm{N}$ in the Ae horizon were significantly related to the amounts in the forest-floor horizon (i.e., $\mathrm{L}$ $+\mathrm{F}+\mathrm{H}, r=0.635, P<0.05)$. The amounts of $\mathrm{NO}_{3}{ }^{-} \mathrm{N}$ accumulated on the resin in the Ae horizons increased as the amounts increased in the forest-floor horizon, suggesting that nitrate released in the organic layers is leached down to the Ae horizon. Mitchell et al. (1992b) have reported that the dominant form of inorganic $\mathrm{N}$ leached through forest soils is $\mathrm{NO}_{3}{ }^{-}-\mathrm{N}$ in hardwood forests. Rates of $\mathrm{NH}_{4}{ }^{+}-\mathrm{N}$ accumulation on the resin varied from 0.5 to $6 \mu \mathrm{g} 10 \mathrm{~cm}^{-2} 2 \mathrm{wk}^{-1}$ for the Ae horizon and from 0.4 to $12 \mu \mathrm{g} 10 \mathrm{~cm}^{-2} 2 \mathrm{wk}^{-1}$ for the forest-floor horizons. Unlike $\mathrm{NO}_{3}{ }^{-}-\mathrm{N}$, there was no relationship for $\mathrm{NH}_{4}{ }^{+} \mathrm{N}$ between the Ae and forest-floor horizons, presumably because $\mathrm{NH}_{4}{ }^{+}-\mathrm{N}$ is not as susceptible to leaching as $\mathrm{NO}_{3}{ }^{-}-\mathrm{N}$.

The $\mathrm{F}$ and $\mathrm{H}$ horizons released more $\mathrm{N}$ by mineralization than the L horizon (Boone 1992; Persson and Wirén 1995). The results of the laboratory incubations, where leaching is not a factor, support these findings (Fig. 5). Relative supply rates of $\mathrm{NO}_{3}{ }^{-}-\mathrm{N}$ ranked by horizons were $\mathrm{H}>\mathrm{F}>\mathrm{L}>\mathrm{Ae}$. Among the $\mathrm{L}, \mathrm{F}$ and $\mathrm{H}$ horizons, the $\mathrm{L}$ horizon had the lowest
$\mathrm{N}$ release rates presumably because it was composed mainly of litter less than $1 \mathrm{yr}$ old and had the largest $\mathrm{C}: \mathrm{N}$ ratio. The quantity of soil inorganic $\mathrm{N}\left(\mathrm{NO}_{3}{ }^{-} \mathrm{N}\right.$ and $\left.\mathrm{NH}_{4}{ }^{+}-\mathrm{N}\right)$ adsorbed by the resin membranes in the laboratory study was significantly higher $(P<0.0001)$ than in the field (Fig. $5 \mathrm{a}$ and $\mathrm{b}$ ). In the Ae horizon however, the quantity of soil inorganic $\mathrm{N}$ adsorbed by the resin membranes in the laboratory was significantly lower $(P<0.05)$ than in the field (Fig. $5 \mathrm{a}$ and $\mathrm{b}$ ), indicating the importance of physical processes such as leaching in redistributing nitrate in the field.

Soil inorganic P supply rates varied from 0.11 to $19 \mu \mathrm{g} 10$ $\mathrm{cm}^{-2} 2 \mathrm{wk}^{-1}$ for the Ae horizon and from 0.06 to $41 \mu \mathrm{g} 10$ $\mathrm{cm}^{-2} 2 \mathrm{wk}^{-1}$ for the forest floor horizons (Fig. 6). On average, the $\mathrm{H}$ horizon had the highest $\mathrm{P}$ supply rate, followed by the $\mathrm{F}$ horizon and the $\mathrm{L}$ horizon. The results suggest that large inputs of decomposable organic matter combine with low $\mathrm{P}$ adsorption capacity to promote rapid $\mathrm{P}$ mineralization and $\mathrm{P}$ uptake in the forest floor horizons. In addition to organic matter mineralization, $\mathrm{P}$ is supplied by inorganic sources in the mineral soil. However, $\mathrm{P}$ supply rate is low in the Ae horizon because $\mathrm{P}$ is adsorbed tightly by clays, compared to organic matter in the forest floor horizons.

Unlike $\mathrm{NO}_{3}{ }^{-}-\mathrm{N}$, there was no relationship between $\mathrm{P}$ accumulation in the Ae horizon and in the forest-floor horizon. The increase in $\mathrm{P}$ from the forest floor to the mineral soil through leaching was small (Johnson 1989). In laboratory incubations, relative release rates of $\mathrm{P}$ were highest in the $\mathrm{F}$ horizon, followed by the $\mathrm{L}$ horizon, the $\mathrm{H}$ horizon, and lowest in the Ae horizon (Fig. 5c). The F horizon released the most mineralized $\mathrm{P}$ because the horizon is composed mostly of foliar litter at an intermediate stage of litter decomposition. Forest ecosystems may obtain the majority of their annual $\mathrm{P}$ requirements from biological recycling rather than from geochemical sources (Sollins et al. 1980). Decomposer organisms and absorbing roots are concentrated in the forest floor, where the organic P enters the soil system. For example, electron micrographs have shown fungal hyphae connecting living roots and decomposing leaves in soil (Herrara et al. 1978). The general hypothesis is that $\mathrm{P}$ mineralized from litter by decomposers in the litter layer may pass directly to plant roots with little or no leaching to the mineral soil, although translocation by water may take place within the forest floor horizons. Our results support the hypothesis that large amounts of $\mathrm{P}$ are released from the organic layers and subsequently taken up by plants under field conditions. The quantity of soil inorganic $\mathrm{P}$ adsorbed by the resin membrane was much higher $(P<0.0001)$ in the laboratory incubations than in the field (Fig. 5c), reflecting the influence of accelerated mineralization under favorable temperature and moisture conditions and lack of plant uptake in the laboratory, as compared to in the field.

\section{Seasonal Patterns in Nitrogen and Phosphorus Plant Uptake}

Plant uptake of $\mathrm{N}$, as calculated by the difference in nutrient ion supply rate, and nutrient ion levels inside and outside PVC cylinders, exhibited a bell-shaped seasonal curve, with highest plant uptake (inside - outside the cylinders) in summer (Fig. 7). Minimum uptake was in spring for $\mathrm{NO}_{3}{ }^{-}-\mathrm{N}$ and in 


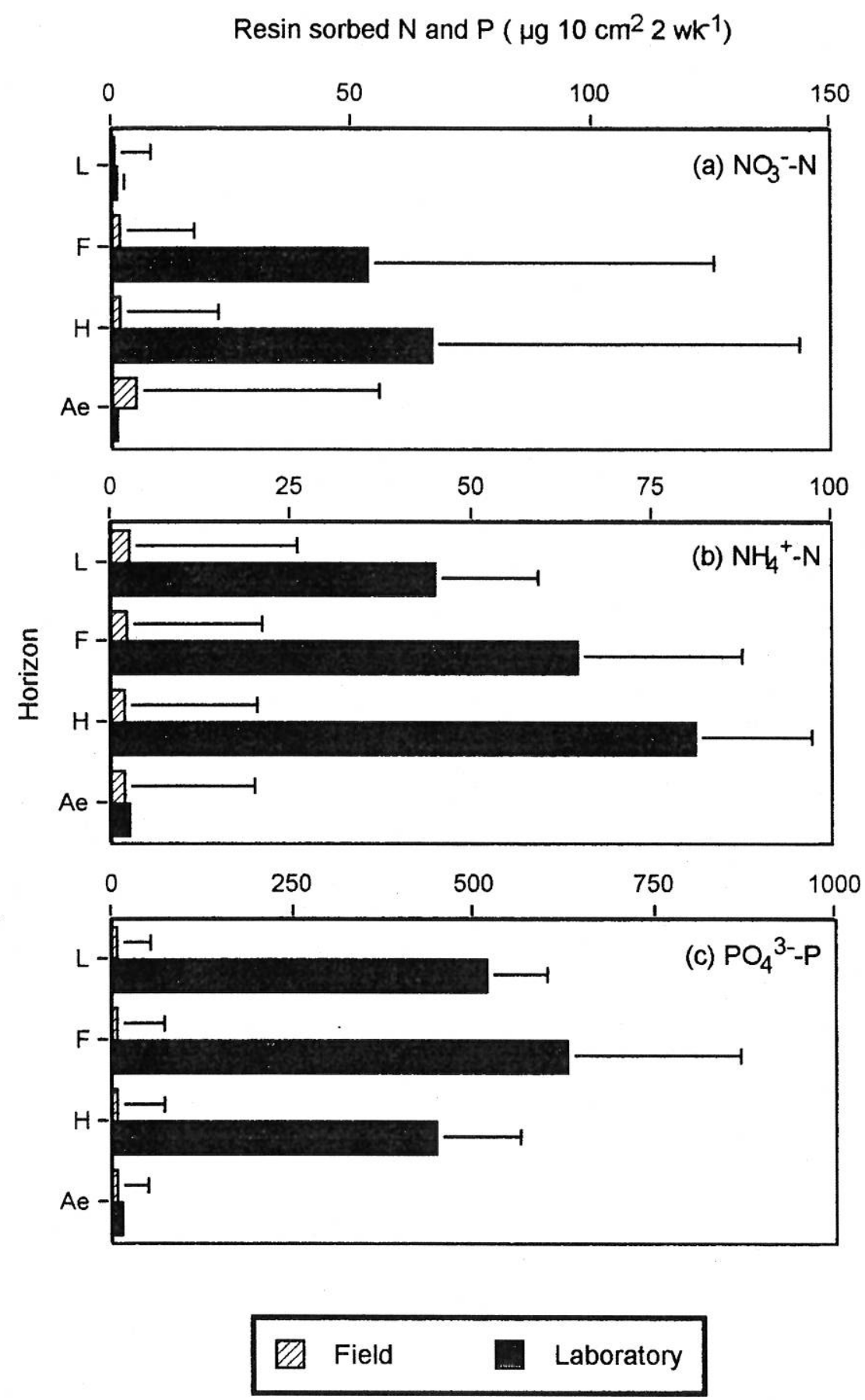

Fig. 5. Comparison of $\mathrm{N}$ and $\mathrm{P}$ (mean + one standard deviation) adsorbed on the resin membranes during a 2-wk burial in the field and laboratory.

October for $\mathrm{NH}_{4}{ }^{+}-\mathrm{N}$. The patterns of $\mathrm{N}$ uptake did not follow the patterns observed for $\mathrm{N}$ input by bulk deposition and throughfall over the growing season (Fig. 7c), suggesting a dominant role played by mineralization in supplying plant available $\mathrm{N}$. The highest monthly input of $\mathrm{N}$ by throughfall was observed in June when the canopy consisted of newly growing leaves, and the lowest in May and October when the trees were leafless at the study site. Over the growing season, bulk deposition and throughfall contributed $1.8 \mathrm{~kg}$ $\mathrm{NH}_{4}{ }^{+}-\mathrm{N} \mathrm{ha}{ }^{-1}$ in total (Table 3), of which $48 \%$ was from bulk deposition alone, $39 \%$ from aspen throughfall and $23 \%$ from hazel throughfall. For $\mathrm{NO}_{3}^{-}-\mathrm{N}$, bulk deposition and throughfall contributed $0.23 \mathrm{~kg} \mathrm{ha}^{-1}$, of which $57 \%$ was from hazel throughfall, $39 \%$ from bulk deposition alone and 


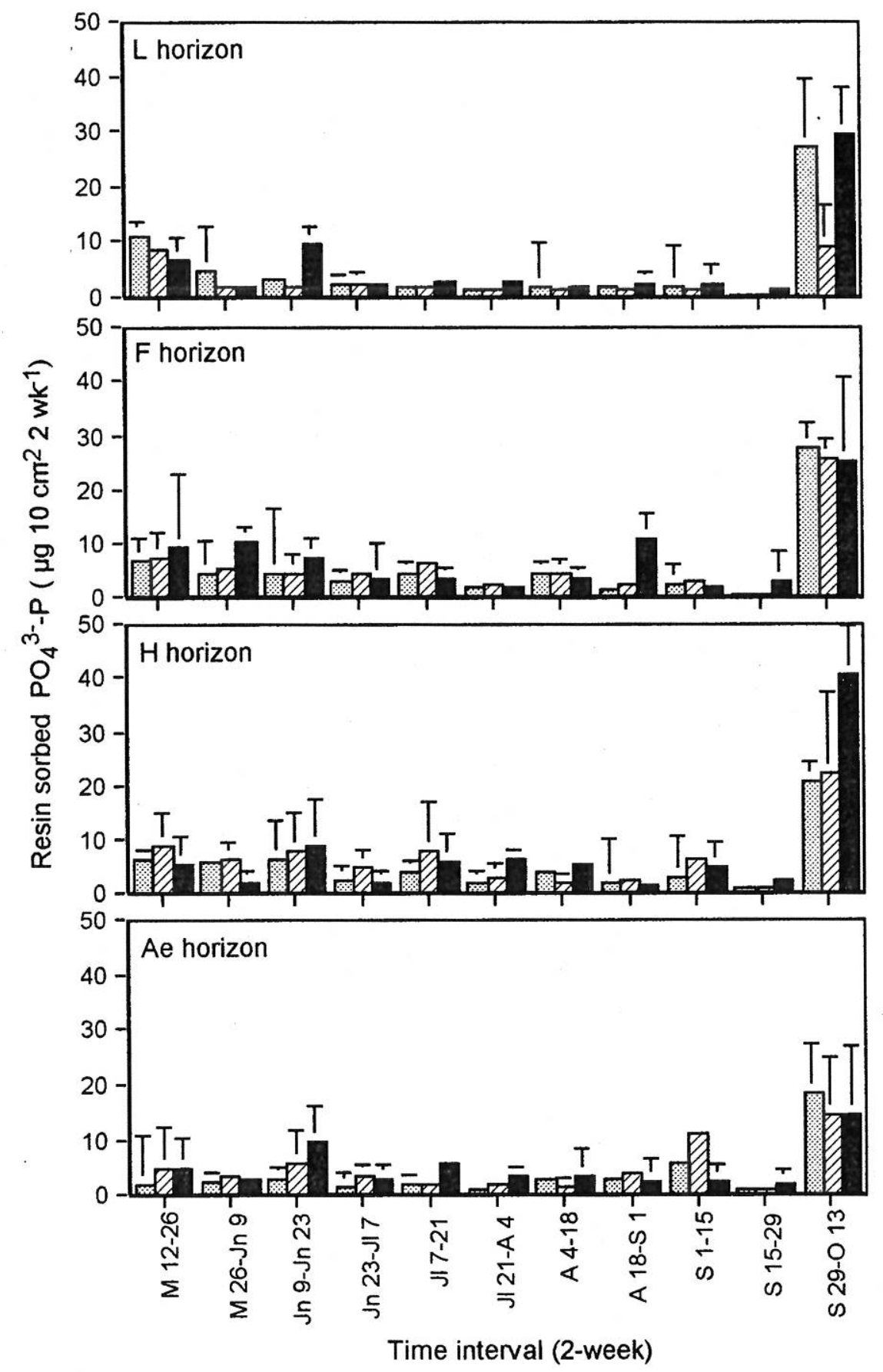

\section{Top slope $\square$ Mid slope $\square$ Low slope}

Fig. 6. Seasonal and spatial patterns in soil P supply rate in different horizons and slope positions at the study area (12 May to 13 October 1994). Bars refer to one standard deviation.

4\% from aspen throughfall. Notwithstanding high spatial variability and low sample sizes, it can still be seen that a large proportion of the throughfall and bulk deposition $\mathrm{N}$ input was in organic form $(68 \%)$.
Soil $\mathrm{N}$ can be taken up as both $\mathrm{NO}_{3}{ }^{-}-\mathrm{N}$ and $\mathrm{NH}_{4}{ }^{+} \mathrm{N}$ by trees and understory plants in forest ecosystems. Plant uptake of $\mathrm{NH}_{4}{ }^{+} \mathrm{N}$ is more important in conifer stands than in deciduous stands (Nadelhoffer et al. 1984). In the current 

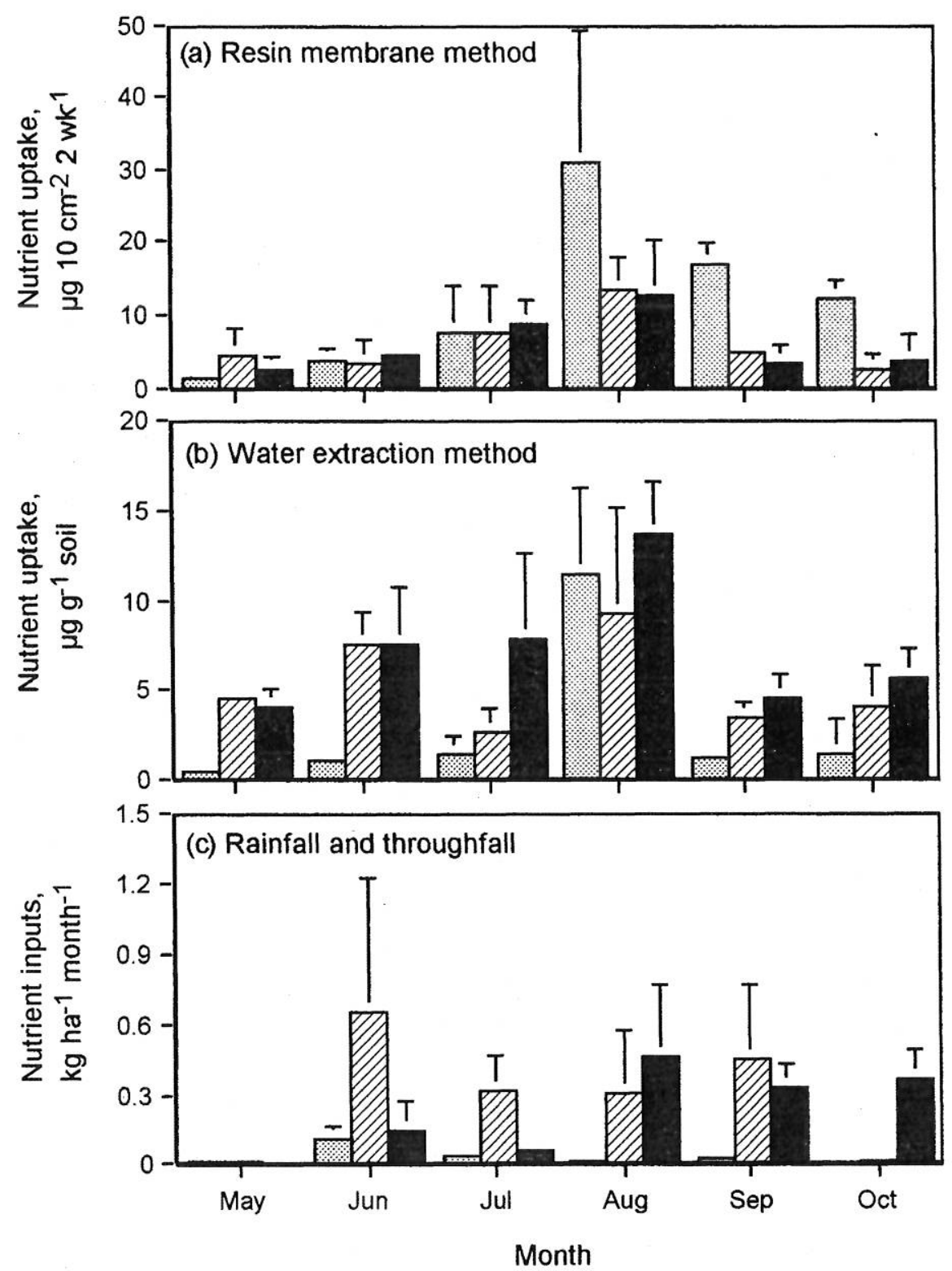

\section{$\mathrm{NO}_{3}-\mathrm{N} \square \mathrm{NH}_{4}{ }^{+}-\mathrm{N} \square \mathrm{PO}_{4}{ }^{3-}-\mathrm{P}$}

Fig. 7. Seasonal patterns in $\mathrm{N}$ and $\mathrm{P}$ uptake by vegetation and inputs of $\mathrm{N}$ and $\mathrm{P}$ by bulk deposition and throughfall over the growing season at the study site. Bars refer to one standard deviation (17 May to 12 October 1995).

Note: Nutrient uptake = inside - outside the cylinders.

study, we found that the dominant form of $\mathrm{N}$ taken up by trees varied during the growing season. In early spring (May), $\mathrm{NH}_{4}{ }^{+}-\mathrm{N}$ appeared to be the dominant form of $\mathrm{N}$ taken up by roots, in June and July similar amounts of $\mathrm{NO}_{3}^{-}-\mathrm{N}$ and $\mathrm{NH}_{4}^{+}-\mathrm{N}$ are taken up, and in summer and fall, $\mathrm{NO}_{3}^{-}-\mathrm{N}$ is the dominant form assimilated.

Similar to $\mathrm{N}$ uptake, $\mathrm{P}$ uptake exhibited a bell-shaped seasonal curve (Fig. 7), and did not follow the patterns observed for P input by bulk deposition and throughfall at the study site (Fig. 8c). Over the growing season, $1.4 \mathrm{~kg} \mathrm{ha}^{-1}$ (Table 3 ) of inorganic $\mathrm{P}$ was added to the soil by bulk deposition and throughfall, of which $47 \%$ was from hazel throughfall, $41 \%$ from aspen throughfall and $12 \%$ from bulk deposition alone. A very small portion of the $\mathrm{P}$ input by bulk deposition and throughfall was in organic form (14\%). Maximum uptake of $\mathrm{P}$ occurred in August and was lowest in 


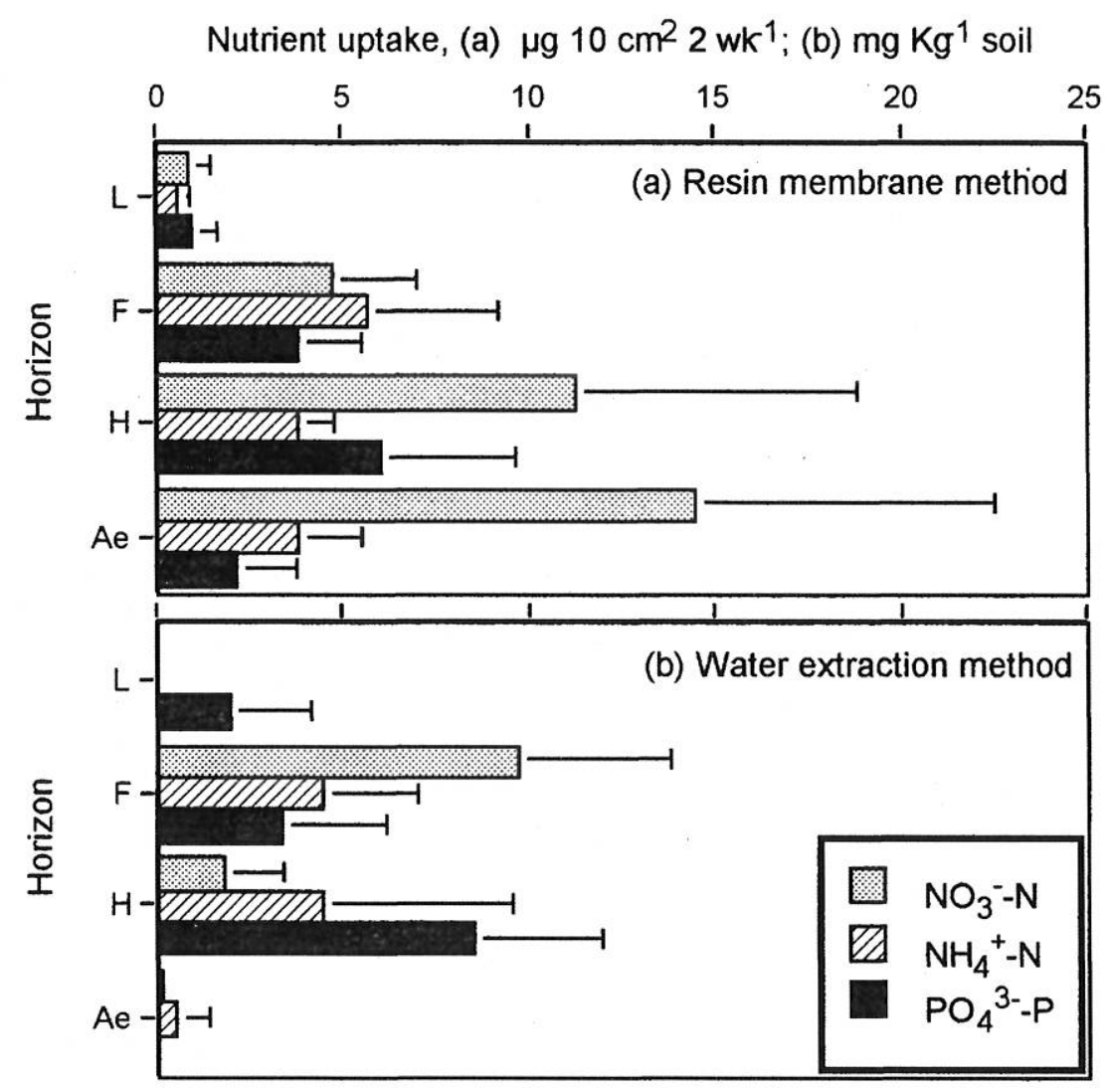

Fine root biomass, $\mathrm{kg} \mathrm{m}^{3}$

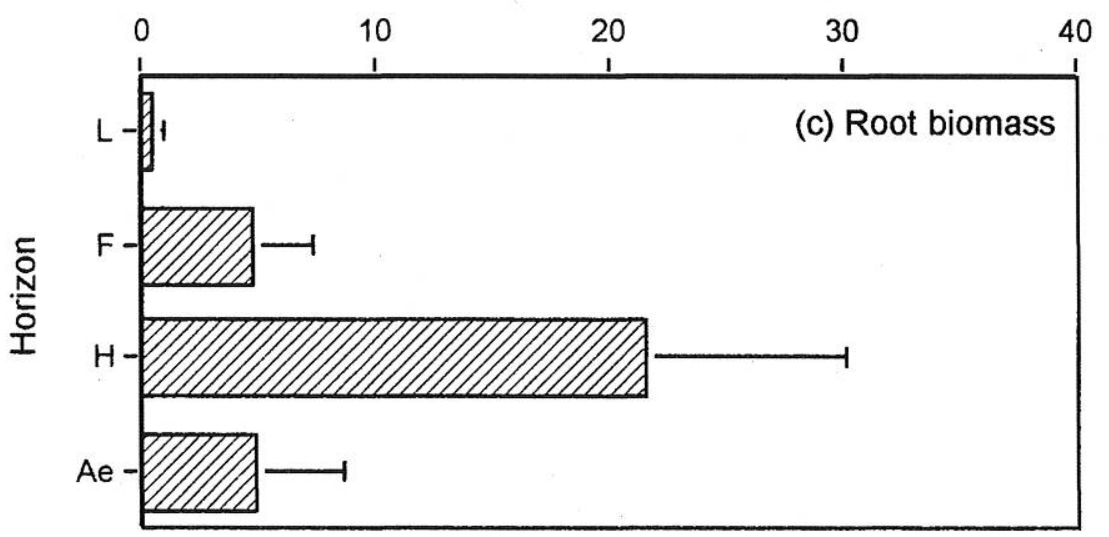

Fig. 8. Vertical patterns in $\mathrm{N}$ and $\mathrm{P}$ uptake by vegetation and fine root biomass in different horizons at the study site. Bars refer to one standard deviation (August 1995): (a) N and P measured by IEM in the field burial method; (b) water soluble N and P; and (c) Fine root biomass.

May. Plant uptake of $\mathrm{P}$ as assessed by the water soluble $\mathrm{P}$ showed similar patterns over the growing season (Fig. 7b).

\section{Vertical Patterns in Nitrogen and Phosphorus Plant Uptake}

In addition to seasonal patterns, $\mathrm{N}$ and $\mathrm{P}$ uptake exhibited spatial patterns. The spatial patterns in $\mathrm{N}$ and $\mathrm{P}$ uptake were similar to those observed for fine root distribution in most cases (Fig. 8), with greatest uptake coinciding with predominance of fine roots in the $\mathrm{H}$ horizon.

The highest concentration of roots is in the lower portion of the humus layer in some boreal forest stands, including aspen (Strong and La Roi 1985). Although the present data were only for one site, it can still be seen that the highest uptake of $\mathrm{N}$ occurred in the $\mathrm{H}$ horizon, followed by the $\mathrm{F}$ horizon, the Ae horizon, with the lowest in the L horizon. 
This can be attributed to higher rates of $\mathrm{N}$ mineralization generally occurring in the lower organic horizons (Boone 1992; Persson and Wirén 1995) where most of the fine root growth is concentrated.

Figure 8 illustrates the vertical patterns in $\mathrm{P}$ uptake in the soil profiles at the study area. The L, F, H and Ae horizons showed variability by horizon with respect to $\mathrm{P}$ uptake. On average, the highest $\mathrm{P}$ uptake occurred in the $\mathrm{H}$ horizon, followed by the F horizon, the Ae horizon, and the lowest was in the $\mathrm{L}$ horizon. Phosphorus in forest soils is strongly and positive correlated with root density, and the relationship between roots and $\mathrm{P}$ content is biologically significant (Strong and La Roi 1985). This is perhaps related to the presence of decomposer organisms, fungal hyphae and absorbing roots that are concentrated in the forest floor (Herrara et al. 1978). Stark and Jordan (1978) provided direct evidence that plant roots may take up dissolved nutrients before they leach down to mineral soil. In the present study, $\mathrm{P}$ uptake was significantly correlated to fine root biomass $(P<0.05, r=0.92$ and 0.89 for IEM- and water-P, respectively).

\section{CONCLUSIONS}

The supply rate of $\mathrm{N}$ and $\mathrm{P}$ in the forest floor and surface mineral soil varied greatly by season and horizon. However, there was no significant difference in nutrient supply rate among aspects at the study site. Nutrient ion supply rates were significantly higher in laboratory incubations than in the field, especially for P. The favorable temperature and moisture conditions for microbial activity in the laboratory incubations probably contributed to a higher release rate of inorganic ions compared to the field. As well, competition for ions takes place between the resin and plant roots in the field. Differences between nutrients inside and outside cylinders inserted into soil to exclude roots can be used to determine patterns of plant uptake. Summer is the period of active plant nutrient mineralization and uptake in the boreal aspen forest. In general, most of the $\mathrm{N}$ and $\mathrm{P}$ uptake takes place in the $\mathrm{H}$ horizon, where the plant fine roots are concentrated. Late fall is an important time for nutrient recycling back into available forms, with replenishment of bioavailable forms coinciding with late season litterfall. Bulk deposition and throughfall inputs of nutrients, though small, likely play an important role as a long-term source of plant nutrient to replace those lost from the system by leaching or volatilization.

\section{ACKNOWLEDGEMENTS}

We thank Catharine MacLeod for her help in sampling and separating the roots, and Jackie Moir, Xiuxian Chen and Leslie Surtees for their technical assistance in the laboratory. The financial support of this research project was provided by the Natural Science and Engineering Research Council of Canada (NSERC). Special thanks are extended to the Boreal Ecosystem-Atmosphere Study (BOREAS) project for providing the research opportunities. The valuable comments from two anonymous reviewers are greatly appreciated.
Abacus Concepts, Inc. 1989. Abacus Concepts, SuperANOVA ${ }^{\mathrm{TM}}$. Abacus Concepts, Inc. Berkeley, CA.

Adams, J. A. 1986. Nitrification and ammonification in acid forest litter and humus as affected by peptone and ammonium nitrogen amendment. Soil Biol. Biochem. 18: 45-51.

Adams, M. A. and Attiwill, P. M. 1986. Nutrient cycling and nitrogen mineralization in eucalpt forests of southeastern Australia. II. Indices of nitrogen mineralization. Plant Soil 92: 341-362.

Adams, M. A., Polglase, P. J., Attiwill, P. M. and Weston, C. J. 1989. In situ studies of nitrogen mineralization and uptake in forest soils; some comments on methodology. Soil Biol. Biochem. 21: 423-429.

Alban, D. H. 1982. Effects of nutrient accumulation by aspen, spruce, and pine on soil properties. Soil Sci. Am. J. 46: 853-861. Arp, P. A. and Krause, H. H. 1984. The forest floor: Lateral variability as revealed by systematic sampling. Can. J. Soil Sci. 64: 423-437.

Bernier, B. 1984. Nutrient cycling in Populus: a literature review with implications in intensively-managed plantations. For. Energy Agreement, Int, Energy Agency, Stockholm, Sweden and Environ. Canada, Canadian Forest Service, Ottawa, ON. IEA/ENFOR Joint Rep.

Binkley, D. 1984. Ion exchange resin bag: factors affecting estimates of nitrogen availability. Soil Sci. Soc. Am. J. 47: 1181-1184. Blew, R. D., Iredale, D. R. and Parkinson, D. 1993. Throughfall nitrogen in a white spruce forest in southwest Alberta, Canada. Can. J. For. Res. 23: 2389-2394.

Boone, R. D. 1992. Influence of sampling date and substrate on nitrogen mineralization: comparison of laboratory-incubation and buried-bag methods for two Massachusetts forest soils. Can. J. For. Res. 22: 1895-1900.

Boyle, J. R., Phillips, J. J. and Ek, A. R. 1973. Whole tree harvesting: Nutrient budget evaluation. J. For. 71: 760-762.

Canada Soil Survey Committee. 1987. The Canadian system of soil classification 2nd ed. Agriculture Canada, Ottawa, ON. Publ. 1646, 164pp.

Casals, P., Romanya, J., Cortina, J., Fons, J., Bode, M. and Vallejo, V. R. 1995. Nitrogen supply rate in Scots pine (Pinus sylvestris L.) forests of contrasting slope aspect. Plant Soil 168-169: 67-73.

Cole, D. W. 1995. Soil nutrient supply in natural and managed forests. Plant Soil 168-169: 43-53.

Cooperband, L. R. and Logan, T. J. 1994. Measuring in situ changes in labile soil phosphorus with anion-exchange membranes. Soil Sci. Soc. Am. J. 58: 105-114.

Federer, C. A. 1983. Nitrogen mineralization and nitrification: depth variation in four New England forest soils. Soil Sci. Soc. Am. J. 47: 1008-1014.

Forestry Canada. 1988. Canada's forest inventory 1986. Forestry Canada, Petawawa National Forestry Institute, Chalk River, ON.

Gales, E. M., Julian, Jr, E. C. and Kroner, R. C. 1966. Method for quantitative determination of total phosphorus in water. Am. Water Works Assoc. J. 58: 1363-1368.

Gibson, D. J. 1986. Spatial and temporal heterogeneity in soil nutrient supply measured using in situ-exchange resin bags. Plant Soil 96: 445-450.

Gibson, D. J., Colquhoun, I. A. and Greig-Smith, P. 1985. A new method for measuring nutrient supply rates in soils using ionexchange resins. Pages 73-79 in A. H. Fitter, D. Atkinson, D. J. Read, and M. B. Usher, eds. Ecological interactions in soil. Special publication number 4 of the British Ecological Society. Blackwell Scientific Publications, Oxford, UK. 
Gosz, J. R., Likens, G. E. and Bormann, F. H. 1972. Nutrient content of litter fall on the Hubbard Brook Experimental Forest, New Hampshire. Ecology 53: 769-784.

Hart, S. C. and Firestone, M. K. 1991. Forest floor-mineral soil interactions in the internal nitrogen cycle of an old-growth forest. Biogeochemistry 12: 103-127.

Herrara, R., Merida, T., Stark, N. and Jordan, C. F. 1978. Direct phosphorus transfer from leaf litter to roots. Naturwissenschanften 65: 208-209.

Huang, W. Z. and Schoenau, J. J. 1996a. Microsite assessment of forest soil N, P and K supply rates in-field using ion exchange membranes. Commun. Soil Sci. Plant Anal. 27: 2895-2908.

Huang, W. Z. and Schoenau, J. J. 1996b. Distribution of water soluble organic carbon in an aspen forest soil. Can. J. For. Res. 26: 1266-1272.

Johnson, C. E. 1989. The chemical and physical properties of a northern hardwood forest soil: Harvest effects, soil-tree relations, and sample size determination. Ph.D. Diss. University of Pennsylvania, Philadelphia, PA.

Johnson, D. W. and Todd, S. E. 1987. Nutrient export by leaching and whole-tree harvesting in a loblolly pine and mixed oak forest. Plant Soil 102: 99-109.

Menzel, D. W. and Corwin, N. 1965. The measurement of total phosphorus in seawater based on the liberation of organically bound fractions by persulfate oxidation. Limnol. Oceanogr. 10: 280-282.

Mitchell, M. J., Burke, M. K. and Shepard, J. P. 1992a. Seasonal and spatial patterns of S, Ca, and $\mathrm{N}$ dynamics of a northern hardwood forest ecosystem. Biogeochem. 17: 165-189.

Mitchell, M. J., Foster, N. W., Shepard, J. P. and Morrison, I. K. 1992b. Nutrient cycling in Huntington forest and Turkey Lakes deciduous stands: nitrogen and sulfur. Can. J. For. Res. 22: 457-464.

Murphy, J. and Riley, J. P. 1962. A modified single solution method for the determination of phosphates in natural waters. Anal. Chem. Acta. 27: 31-36.

Nadelhoffer, K. J., Aber, J. D. and Melillo, J. M. 1984. Seasonal patterns of ammonium and nitrate uptake in nine temperate forest ecosystems. Plant Soil 80: 321-335.

Nadelhoffer, K. J., Aber, J. D. and Melillo, J. M. 1985. Fine roots, net primary production, and soil nitrogen availability: a new hypothesis. Ecology 66: 1377-1390.

Nilsson, L. O., Hüttl, R. F., Johansson, O. O. and Jochheim, H. 1995. Nutrient uptake and cycling in forest ecosystems - present status and future research directions. Plant Soil 168-169: 5-13.

Perala, D. A. and Alban, D. H. 1982. Biomass, nutrient distribution and litterfall in Populus, Pinus and Picea stands on two different soils in Minnesota. Plant Soil 64: 177-192.

Persson, T. and Wirén, A. 1995. Nitrogen mineralization and potential nitrification at different depths in acid forest soils. Plant Soil 168-169: 55-65.

Qian, P. and Schoenau, J. J. 1995. Assessing nitrogen mineralization from soil organic matter using anion exchange membranes. Fert. Res. 40: 143-148.

Qian, P. and Schoenau, J. J. 1997. Recent developments in use of ion exchange membranes in agricultural and environmental research. Rec. Res. Devel. Soil Sci. (in press).

Quesnel, H. J. and Lavkulich, L. M. 1981. Comparison of the chemical properties of forest floors, decaying wood, and fine roots in three ecosystems on Vancouver Island. Can. J. For. Res. 11: 215-217.

Raison, R. J., Connell, M. J. and Khanna, P. K. 1987. Methodology for studying fluxes of soil mineral $\mathrm{N}$ in situ. Soil Biol. Biochem. 19: 521-530.
Raulund-Rasmussen. K. and Vejre, H. 1995. Effect of tree species and soil properties on nutrient immobilization in the forest floor. Plant Soil 168-169: 345-325.

Raveh, A. and Avnimelech, Y. 1979. Total nitrogen analysis in water, soil and plant material with persulfate oxidation. Water Res. 13: 911-912.

Schoenau, J. J. and Greer, K. 1996. Field mapping of soil nutrient supply rates. Better crops with plant food. No. 3: 12-13. Potash and Phosphate Institute, Norcross, GA.

Schoenau, J. J. and Huang, W.Z. 1991. Assessing P, N, S and K availability in soil using anion and cation exchange membranes. Pages 131-136 in Proceedings of the Western Phosphate and Sulfur Workgroup. Colorado State University, Fort Collins, CO.

Schoenau, J. J., Qian, P. and Huang, W. Z. 1993. Assessing sulfur availability in soil using ion exchange membranes. Sulfur Agric. 17: 13-17.

Silkworth, D. R. and Grigal, D. F. 1982. Determining and evaluating nutrient losses following whole-tree harvesting of Aspen. Soil Sci. Soc. Am. J. 46: 626-631.

Skogley, E. O., Georgitis, S. J., Yang, J. E. and Schaff, B. E. 1990. The phytoavailability soil test - PST. Commun. Soil Sci. Plant Anal. 21: 1229-1243.

Sollins, P., Grier, C. C., McCorison, Jr., F. M., Cromack, K., Fogel, R. and Fredriksen, R. L. 1980. The internal element cycles of an old-growth Douglas-fir ecosystem in Western Oregon. Ecol. Monogr. 50: 261-285.

Sorn-Srivichai, P., Syers, J. K., Tillman, R. W. and Cornforth, I. S. 1988. An evaluation of water extraction as a soil-testing procedure for phosphorus. I. Glasshouse assessment of plant-available phosphorus. Fert. Res. 15: 211-223.

Stark, N. and Jordan, C. F. 1978. Nutrient retention by the root mat of an Amazonian rain forest. Ecology 59: 434-437.

Strong, W. L. and La Roi, G. H. 1985. Root density - soil relationships in selected boreal forests of central Alberta, Canada. For Ecol. Manage. 12: 233-251.

Technicon. 1973. Technicon AutoAnalyzer ${ }^{\mathrm{TM}}$. II. Industrial method. No. 100-70W. Technicon Instruments Corporation, Tarrytown, NY

Thomas, R. L., Sheard, R. W. and Moyer, J. P. 1967. Comparison of conventional and automated procedures for nitrogen, phosphorus, and potassium analysis of plant material using a single digest. Agron. J. 99: 240-243.

Tietema, A. L., De Boer, W., Riemer. L. and Verstraten, J. M. 1992. Nitrate production in nitrogen-saturated acid forest soils: vertical distribution and characteristics. Soil Biol. Biochem. 24: 235-240.

Tietema, A. L., Riemer, L., van der Maas, M. P., van Wijk, A. J. and van Voorthuyzen, I. 1993. Nitrogen cycling in acid forest soils subject to increased atmospheric nitrogen input. For. Ecol. Manage. 57: 29-44.

Vitousek, P. M. and Matson, P. A. 1985. Disturbance, nitrogen availability, and nitrogen losses in an intensively managed loblolly pine plantation. Ecology 66: 1360-1376.

White, C. S., Moore, D. I., Horner, J. D. and Gosz, J. R. 1988. Nitrogen mineralization-immobilization response to field $\mathrm{N}$ or $\mathrm{C}$ perturbations: an evaluation of a theoretical model. Soil Biol. Biochem. 20: 101-105.

Yang, J. E. and Jacobsen, J. S. 1990. Soil inorganic phosphorus fractions and their uptake relationship in calcareous soils. Soil Sci. Soc. Am. J. 54: 1666-169.

Zhang, Y. and Mitchell, M. J. 1995. Phosphorus cycling in a hardwood forest in the Adirondack Mountains, New York. Can. J. For. Res. 25: 81-87. 